\title{
Avrupa Birliği Döngüsündeki Ülkelerin Sağlık Sistemleri Performanslarının Karşılaştırılması
}

\author{
Mesut TELEŞ* ${ }^{*}$ Cuma ÇAKMAK ${ }^{* *}$ Murat KONCA ${ }^{* * *}$
}

$\ddot{O} Z$

Sağlık sistemlerinin başarısını engelleyen faktörler, teknik sinırlılıklardan ziyade sistemsel başarısızlıklardır, yani sağllk sistemlerinin başarısızlı̆̆ının temel sebebi bilgi eksikliği değil, bilinenin tam olarak uygulanamamasıdır. Bu durum sağlık sistemlerinin mevcut performansların karşılaş̧ırmayı ve bu sistemlerin potansiyellerini nasıl hayata geçirebileceklerini tartışmayı gerektirmektedir. Bu kapsamda bu çalışmada Avrupa Birliği (AB) döngüsündeki ülkelerin sağllk sistemlerinin verimlilik performansları Veri Zarflama Analizi (VZA) ile karşılaştırılmıştır. Karşılaştırma yapılmadan önce kümeleme analizi yapılarak karşılaştırılan ülkelerin kendi içinde homojen, aralarında ise hetorojen olmaları sağlanmıştır. Çalışma kapsamında hem kümelere göre hem de AB döngüsündeki ülkelerin tamamına göre VZA yapılmıştır. Analiz sonuçlarına göre, birinci kümede yer alan ülkelerin $\% 56,25$ ' $i$, ikinci kümede yer alan ülkelerin $\% 65$ 'i verimli bulunmuştur. AB döngüsündeki ülkelerin tamamının, herhangi bir kümeleme olmadan yer aldı̆̆ analizde ise ülkelerin $\% 58,33$ 'ü verimli bulunmuştur.

Anahtar Kelimeler: Sağlık Sistemleri, Performans, Kümeleme Analizi, Veri Zarflama Analizi

JEL Sinıflandirması: I18, C67, I10, O57

\section{Comparison of Health Systems Performance of Countries in the European Union Cycle}

\begin{abstract}
The factors that hamper the success of health systems are the systemic failures rather than technical limitations, that is, the main reason for the failure of health systems is not the lack of knowledge, but not the full implementation of what is known. This necessitates comparing the current performance of health systems and discussing how they can realize their potentials. In this context, the efficiency performance of the health systems of countries in the European Union (EU) cycle is compared with Data Envelopment Analysis (DEA). Prior to comparison, clustering analysis was performed to ensure the homogeneity of the clusters within themselves while to ensure the heterogenity between themselves. According to the results of the analysis, $56.25 \%$ of the countries in the first cluster and $65 \%$ of the countries in the second cluster were found to be efficient. In the analysis where all of the countries in the EU cycle were involved without any clustering, $58.33 \%$ of the countries were found to be efficient.
\end{abstract}

Key Words: Health Systems, Performance, Cluster Analysis, Data Envelopment Analysis JEL Classification: I18, C67, I10, O57

\footnotetext{
*Araştırma Görevlisi Dr., Niğde Ömer Halisdemir Üniversitesi Sağlık Yönetimi Bölümü. mesutteles@hotmail.com

${ }^{* *}$ Araştırma Görevlisi, Hacettepe Üniversitesi Sağlık Yönetimi Bölümü cumacakmak@hacettepe.edu.tr

***Araştırma Görevlisi, Hacettepe Üniversitesi Sağlık Yönetimi Bölümü konca71@gmail.com 


\section{GíRIŞ}

Sağlık sistemleri, öncelikli amacı sağlığ iyileştirmek olan tüm bireyleri ve faaliyetleri kapsayan sistemlerdir ve bu sistemler, bilginin kazanılması ve uygulamaya konulmasıyla birlikte, özellikle 20. yy.'da ülkelerin sağlık statülerine fazlasıyla katkıda bulunmuştur. Fakat bu katkı başta yoksul kesimler olmak üzere tüm toplumda daha da artırılabilir. Sağlık sistemlerinin potansiyel başarısını engelleyen faktörler, teknik sinırlılıklardan ziyade sistemsel başarısızlıklarıdır, yani sağlık sistemlerinin başarısızlığının temel sebebi bilgi eksikliği değil, bilinenin tam olarak uygulanamamasıdır. Bu durum sağ lık sistemlerinin mevcut performanslarını karşılaştırmayı ve bu sistemlerin potansiyellerini nasıl hayata geçirebileceklerini tartışmayı gerektirmektedir (WHO, 2000).

Bir sağlık sisteminin performans konusunda ne kadar iyi olduğunu ortaya koymak iki önemli soruya cevap vermeyi gerektirmektedir. Birinci soru, performans değerlendirmesinde kullanılacak çıtıların nasıl ölçüleceği iken ikinci soru, sağlık sistemi vasıtasıyla elde edilen kazanımlar ile bu kazanımların sağlık sisteminden beklenenleri karşılayıp karşılamadığının nasıl anlaşılacağıdır (WHO, 2000). The World Health Report 2000 isimli raporunda Dünya Sağlik Örgütü (DSÖ, World Health Organization-WHO) ülkeleri, sağlık sistemi performansı açısından karşılaştırmıştır. DSÖ, ülkelerin sağlık sistemlerini karşılaştırırken performans göstergesi olarak aşağıda açıklanan üç temel amacı gerçekleştirme derecesini dikkate almıştır.

DSÖ (2000)'ye göre sağlık sistemlerinin üç temel amac1; (1) toplumun sağlık statüsünü yükseltmek, (2) beklentileri karşılamak ve (3) hastalıkların maliyetlerine karşı toplumu finansal açıdan adil bir şekilde korumak olarak belirlenmiştir (WHO, 2000). Toplumun sağlık statüsünü yükseltmekten anlaşılması gereken temel husus, toplum sağlığ için elde edilmesi mümkün olan en iyi ortalama seviyeye ulaşmaktır. Bununla birlikte toplumdaki farklı birey ve gruplar arasındaki sağlık statüsü farklılıklarını en aza indirmek de toplumun sağlık statüsünü yükseltmek ifadesinden anlaşılması gerekenler arasındadır. Beklentileri karşılamak, sağlık hizmetleri sunulurken doğrudan sağlık ile ilgili olmayan konularda sağlik sistemlerinin nasıl performans gösterdiği ile ilgilenmektedir. Bu temel amaç; müşteri odaklı olmak, hizmet sunulan bireylere saygılı davranmak, bireylerin haysiyetlerine/bireysel özerkliklerine önem vermek, bilgi gizliliği ve hizmet talep edenlerin hizmet sunucusu seçimi konusunda serbest olmaları gibi konuları kapsamaktadır. Finansmanda adalet ise, bireylerin sağlık finansmanına ne kadar katkıda bulunacaklarının hastalık riskinden ziyade gelirlerine göre belirlenmesi anlamı taşımaktadır (Preker ve Carrin, 2004). DSÖ'nün ülkeleri sağ lık sistemi performansı açısından yukarıda bahsi geçen amaçlara ulaşma derecesine göre karşı1laştırması bazı yazarlarca eleştirilmiştir (Navarro 2000; Blendon, Kim ve Benson, 2001; Almeida, Braveman, Gold vd., 2001). Eleştiriler çoğunlukla; ülkelerin siralanması, ülkelerarası performans değerlendirmesinde sadece anahtar kişilerin görüşlerine başvurulması, verilerin bulunabilirliği ve ülkelerarası karşılaştırılabilirliği gibi konularda yoğunlaşmaktadır (Uğurluoğlu ve Çelik, 2005). 
Ülkelerin sağlık sistemlerinin performansını karşıllaştırırken, çeşitli göstergeler açısından birbirine benzer ülkelerin sağlik sistemlerinin performanslarını birbirleri ile karşılaştırmak, bahsi geçen eleştirilere maruz kalmayı kısmen engellemekte ve karşılaştırılan ülkelere kendi sağlık performanslarını değerlendirme firsatı sunmaktadır (Yıldırım, 2012; Köktaş, 2014). Avrupa Birliği (AB) ülkelerinin sağlık sistemlerinin performanslarını daha önceden karşılaştıran bazı çalışmalar olmakla birlikte (Lorcu, 2008; Yıldırım ve Yıldırım 2011; Asandului, Roman ve Fatulescu, 2014), bu çalışmaların çoğunda ülkelerin tamamı analize dahil edilmemiş, ayrıca her çalışmada kullanılan girdiler ve çıktılar farklılık göstermiştir. $\mathrm{Bu}$ çalı̧̧mada da kullanılan girdi ve çıktılar farklılık göstermekle birlikte, $A B$ döngüsünde bulunan ülkelerin sağlık sistemlerinin performansı veri zarflama analizi (VZA) ile karşılaştırılmadan önce kümeleme analizi yapılmıştır. Böylece, karşılaştırma yapılacak ülkelerin oluşturduğu kümelerin kendi içinde homojenliği, aralarında ise heterojenliği sağlanmıştır. Çalışmanın, AB ölçeğinde şimdiye kadar ülkelerin sağlık sistemlerinin performanslarını karşılaş̧ırmasını yapan çalışmalar arasında, en fazla ülke sayısına sahip çalışma olduğu düşünülmektedir. $\mathrm{AB}$ döngüsündeki ülkeler çerçevesinde; AB'ye üye 28 ülke, AB'ye aday 5 ülke ve Avrupa Serbest Ticaret Birliği (European Free Trade Association/EFTA)'nin üyesi 3 ülke olmak üzere toplam 36 Avrupa ülkesi yer almaktadır (AB Bakanlığı, 2017). Çalışmanın amacı, $\mathrm{AB}$ döngüsündeki bu ülkelerin hem oluşan kümelere göre hem de tamamına göre sağlık sistemlerinin performanslarını VZA tekniği ile karşılaştırmaktır.

\section{I. ÇALIŞMANIN EVRENI}

Çalışmanın evrenini; AB üyesi 28 ülke (Avusturya, Belçika, Bulgaristan, Hırvatistan, Güney Kıbrıs Rum Kesimi ${ }^{1}$ (GKRK), Çek Cumhuriyeti, Danimarka, Estonya, Finlandiya, Fransa, Almanya, Yunanistan, Macaristan, İrlanda, İtalya, Letonya, Litvanya, Lüksemburg, Malta, Hollanda, Polonya, Portekiz, Romanya, Slovakya, Slovenya, İspanya, İsveç ve Birleşik $\mathrm{Krall}_{1}{ }^{2}$ ), Avrupa Birliği'ne aday 5 ülke (Arnavutluk, Karadağ, Makedonya, Sirbistan ve Türkiye) ve EFTA üyesi 3 ülke (İsviçre, İzlanda, Norveç) olmak üzere toplam 36 Avrupa ülkesi oluşturmaktadır. Çalışmada örneklem çekilmemiş, evrenin tamamına ulaşmak hedeflenmiş ve evrenin tamamına ulaşı1mıştır.

\section{II. ÇALIŞMANIN YÖNTEMI}

Çalışma kapsamında, ülkelerin sağlık sistemlerinin performanslarını karşılaştırmada VZA'dan yararlanılmıştır. VZA yöntemi, kendi aralarında homojen oldukları varsayılan karar verme birimlerini kıyaslar (Yıldırım ve Yıldırım, 2011). $\mathrm{Bu}$ nedenle, çalışmada, VZA öncesinde birbirine benzer (homojen) ülkeleri

\footnotetext{
${ }^{1}$ Güney Kıbrıs Rum Kesimi; Türkiye dışındaki Birleşmiş Milletler üyeleri ve Avrupa Birliği üyeleri tarafından Kıbrıs Cumhuriyeti Hükümeti (Government of the Republic of Cyprus) olarak tanınmaktadır.

${ }^{2}$ Haziran 2016'da yapılan referandumdan sonra Birleşik Krallık içerisinde yer alan İngiltere AB üyeliğinden ayrılma kararı almıştır ancak ayrılma işlemlerinin birkaç yıl süreceği düşünülmektedir. Bu yüzden bu çalışma kapsamında Birleşik Krallık, AB üyesi olarak değerlendirilmiştir.
} 
belirleyebilmek için kümeleme analizinden yararlanılmıştır. Aşağıda her iki yöntem hakkında bilgiler sunulmuştur.

\section{A. Kümeleme Analizi}

Küme tanımı genellikle birbirine benzer ya da yakın öğelerin oluşturduğu topluluktur. Kümeleme analizi ise, ham (gruplanmamış) $\mathrm{X}$ veri matrisindeki gözlemleri (bazen de değişkenleri) sahip oldukları özellikler çerçevesinde kümelemek (homojen alt gruplara ayırmak) amacıyla geliştirilmiş yöntemler topluluğudur. Gözlemler; bazen araba markaları, ürünler, hastalık çeşitleri, hastaneler gibi nesneler olabileceği gibi ülkeler de olabilmektedir (Alpar, 2013).

Kümeleme analizi, bir sinıflandırma oluşturmak için kullanılan prosedürleri geniş bir yelpazede sunan sistemlerin genel adıdır. Bu prosedürleri ampirik kümeler veya benzer varlıklar oluşturmaktadır. Daha açık bir ifade ile kümeleme analizi varlık örneklerine ilişkin bilgi içeren veri setleri ile başlayarak bu varlık kümelerine nispeten homojen grupları oluşturmaya çalışan çok değişkenli istatistiksel yöntemlerdir (Alkan, 2012). Diğer çok değişkenli istatistik analizlerde önemli olan verilerin normalliği varsayımı, kümeleme analizinde çok önemli olmayıp uzaklık değerlerinin normalliği yeterli görülmektedir (Öztürk, 2012). Kümeleme analizi sonucunda elde edilecek kümelerin kendi içinde olabildiğince homojen (benzer), kendi aralarında olabildiğince heterojen (farklı) olması beklenir. Kümeleme analizi, temel olarak dört değişik amaca yönelik olarak uygulanan bir yöntemdir (Özdamar, 2013):

1. n sayıda birimi, nesneyi, oluşumu, $p$ değişkene göre saptanan özelliklerine göre olabildiğince kendi içinde türdeş (homojen) ve kendi aralarında farklı (heterojen) alt gruplara (kümelere) ayırmak,

2. $\mathrm{p}$ sayıda değişkeni, $\mathrm{n}$ sayıda birimde saptanan değerlere göre ortak özellikleri açıkladığı varsayılan alt kümeler ayırmak ve ortak faktör yapıları ortaya koymak,

3. Hem birimleri hem de değişkenleri birlikte ele alarak ortak $n$ birimi $p$ değişkene göre ortak özellikli alt kümelere ayırmak,

4. Birimleri, $p$ değişkene göre saptanan değerlere göre, izledikleri biyolojik ve tipolojik siniflamayı ortaya koymak.

Bir veriden elde edilen kümeler, seçilen kümeleme yöntemine göre değişebilmektedir. Kümeleme analizi sonucunda oluşan kümeler yorumlanırken dikkatli olunmalı, kümeler arasında anlamlı farkların olmasına dikkat edilmeli ve sonuçların kuramsal açıdan geçerli olmasına özen gösterilmelidir. Gözlemleri ya da değişkenleri kümelemekte kullanılan yöntemler genellikle aşamalı kümeleme yöntemleri, aşamalı olmayan kümeleme yöntemleri ve iki aşamalı kümeleme yöntemi olmak üzere üç grupta incelenebilir (Alpar, 2013; Özdamar, 2013).

\section{B. Veri Zarflama Analizi}

Veri Zarflama Analizi (VZA) ilk olarak, Farrell (1957) tarafindan yazılan ve her bir karar biriminin verimli üretim sınırıyla karşılaştırılması yoluyla teknik verimliliğin tahmin edildiği "The Measurement of Productive Efficiency" isimli makaleden, Charnes vd. (1978)'nin esinlenerek yazdıkları “ Measuring the 
Efficiency of Decision Making Units" isimli makale ile gündeme gelmiştir. Bu makalede Charnes vd. (1978), Farrell (1957)'de geçen teknik etkinlik tahmini ile üretim sınırlarını iliş̧kilendirme fikrini daha kapsamlı ele almışlardır (Charnes, vd., 1994). Daha sonra Banker vd. (1984), Charnes vd. (1978)'in çalışmasını geliştirip teknik ve ölçek etkinsizliği için modeller önererek Charnes vd. (1978)'in geliştirdikleri ölçekten sabit getiri varsayımı altında tasarlanmış olan modeli (Constant Return to Scale-CRS Modeli ya da yazarların baş harflerinden oluşan şekliyle CCR Modeli) ölçekten değişken getiri formunda (Variable Return to ScaleVRS Modeli ya da yazarların baş harflerinden oluşan şekliyle BCC Modeli) düzenlemişler ve etkinlik ölçümüne yeni bir boyut kazandırmışlardır (Aktaran: Gülsevin ve Türkan, 2012; Demir vd., 2012; Bal ve Bilge, 2013). CRS ve VRS modelleri arasındaki fark şu şekilde ifade edilebilir: "Bir CRS modelinde, girdideki (veya girdilerdeki) artışın çıktılarda oransal değiş̧im yaratacă̆ı varsayılır. Örneğin, bir hastane insan kaynakların \%5 artırmayı planlaniyorsa, bu artışın hastanenin çıktılarında da \%5'lik bir artış yaratacağı varsayılır. Bir VRS modelinde, girdideki (veya girdilerdeki) artışın çıtıllarda artan veya azalan oranda değişim yaratacağ̀ varsayılır. Örneğin, bir hastane insan kaynakların $\% 5$ artırmayı planliyorsa, bu artışın hastanenin çıktılarında \%5'den daha az artış yaratacağl varsayllır." (Narc1, 2012). Bunun yanında CRS modeli hem tamamen yönetsel performanstan kaynaklanan saf teknik verimliliği hem de karar verme biriminin büyüklüğünden kaynaklanan ölçek verimliliğini içerdiğinden toplam verimliliği göstermektedir. VRS modeli ise, büyüklük unsurunu göz ardı ettiğinden ölçek verimliliğini içermeyerek sadece saf teknik verimliliği gösteren modeldir. Bunun bir sonucu olarak, VRS modelinin kullanıldığı bir çalışmada verimli çıkan karar değişkeni sayısı, CRS modeline göre daha fazladır (Narcı, 2012).

Bahsi geçen VZA modelleri, geliştirildikleri günden itibaren göreli verimlilik karşılaştırmalarının yapıldığ 1 birçok çalışmada yöntem olarak kullanılmaktadır (Cooper vd., 2007), hatta performans karşılaştırmalarının yapıldığ 1 parametrik olmayan yaklaşımlar arasında en yaygın kullanılan yöntemlerin başında VZA'nın geldiği söylenebilir (Güran ve Tosun, 2005).

VZA, amacı verileri tek bir regresyon düzleminde en iyi şekilde kullanmak olan parametrik yaklaşımların tersine, her bir gözlemi bir dizi Pareto-Etkin karar birimince oluşturulan ayrık bir parça sınırı hesaplama amacıyla kullanan parametrik olmayan bir yöntemdir. Bunun bir sonucu olarak, tek optimizasyonlu istatistiksel yaklaşımlarda olduğu gibi ortalamalar ve parametrelerin tahminine odaklanmak yerine her bir gözleme odaklanır (Charnes, vd., 1994). Parametrik yöntemlerde, bağımsız değişkenleri bağımlı değişkenlerle ilişkilendirirken regresyon denklemleri ya da üretim fonksiyonları gibi spesifik fonksiyonel bir kalıp dayatılması ve normallik varsayımının sağlanması gibi birtakım kısıtlamalar getirilmesi söz konusu iken parametrik olmayan bir yöntem olan VZA'da araştırmacılara değişken konusunda bir sınırlama getirilmemektedir ve bu özellik, araştırmacılar için istatistiksel çözümlemelerde kolaylıklar sağlamaktadır ki bu durum VZA'nın tercih edilme sebeplerindendir (Charnes vd., 1994; Akkuş, 
Sanisoğlu, Akyol vd., 2006). VZA'nın diğer tercih edilme sebepleri olarak ise; karmaşık girdi ve çıktıya sahip karar verme birimlerini karşılaştırma imkânı sunmas1, verimsiz olan birimlerin verimsiz olmalarına neden olan girdilerinin/çıktılarının neler olduğunu ve bu birimlerin verimli hale gelebilmeleri için verimsizliğe sebep olan girdilerinde/çıktılarında ne miktarda değişim yapılması gerektiğini ortaya koyması ve istenilen sonuçları elde etmede daha başarılı olan birimlere daha çok kaynak ayırma konusunda karar vericilere bilgi sağlaması gösterilebilir (Golany ve Roll, 1989; Şahin, 1999; Aslan, 2007).

VZA'nın yukarıda belirtilen üstünlükleri olduğu gibi bazı zayıf yönleri de mevcuttur. Bu zayıf yönler şu şekilde sıralanabilir (Narc1, 2012; Sarı, 2015):

$\checkmark$ VZA'nın, ölçüm hataları ve değişkenlerin seçimi konularındaki duyarlılığının bir sonucu olarak analiz kapsamındaki herhangi bir karar verme birimine ait girdilerin küçük ya da çıktıların büyük alınması, bu karar biriminin aykırı değer olmasına ve etkinlik sınırının biçiminin bozulmasına yol açarak etkinlik skorlarının gerçeği yansıtmaktan uzaklaşmasına sebep olabilir.

$\checkmark$ Daha önce de belirtildiği gibi VZA, parametrik olmayan bir tekniktir, bu durum VZA'nın sonuçlarına istatistiksel hipotez testlerinin uygulanmasını karmaşık hale getirmektedir.

$\checkmark$ VZA'da her bir karar birimine özel, doğrusal programlama modeli çözümü gerekmektedir. Bunun bir sonucu olarak, büyük boyutlu problemlerin VZA ile çözümü zaman almaktadır.

$\checkmark$ Elde edilen etkinlik skorları yalnızca incelenen gözlem kümesi için geçerlidir, yani farklı karar verme birimlerinin yer alacağı başka bir çalışmadan elde edilen etkinlik skorları ile karşılaştırma yapmak olanaksızdır. Çünkü VZA tekniğinde bir karar verme birimi için atanacak verimlilik skoru, diğer karar verme birimlerine nisbi/göreceli olarak hesaplanır. Bunun sonucu olarak, VZA ile bir defasında verimli bulunan bir karar verme birimi, farklı karar verme birimleri ile karşılaştırıldığında verimsiz bulunabilir.

$\checkmark$ VZA sonuçlarının güvenilir olabilmesi için incelenen karar verme birimlerinin toplam sayısının belirli bir sınırın üzerinde olması gerekmektedir. $\mathrm{Bu}$ sınır konusunda genel kabul görmüş bir sayı yoktur ancak bu sınırın, araştırmada kullanılan girdi ve çıktı değişkenlerinin toplam sayısının en az iki veya üç katı (Behdioğlu ve Özcan, 2009) ya da girdi ve çıktı değişkenlerinin sayısının çarpımı (İlkay ve Doğan, 2009) kadar olması önerilmektedir. Aksi durumda VZA çok sayıda karar verme birimini etkin olarak nitelendirerek yanlış sonuçlar sunmaktadır.

$\checkmark$ Yöntem olarak VZA'nın seçildiği bir çalışmada, araştırma kapsamındaki tüm karar verme birimlerinin örgütsel ve çevresel özelliklerinin benzer olduğu varsayılarak verimsiz çıan karar verme birimlerinin verimsizlik sebeplerinin sadece kötü yönetimler olduğu varsayılır.

VZA, sağlık sistemleri ya da bu sistemlerin vazgeçilmez bileşeni olan hizmet sunumunun gerçekleştiği sağlık kurumları gibi aynı girdiyi kullanıp aynı çıktıyı elde eden karar verme birimlerinin etkinliğini ölçmek için faydalanılan, 
matematiksel doğrusal programlamaya dayalı, parametrik olmayan bir analiz tekniğidir (Rosko, 1990; Bal ve Bilge, 2013; Sarı, 2015). Tek girdi ve çıktının olduğu karar birimlerine ilişkin etkinlik ölçümleri yapmak oldukça basit bir işlemdir ancak birden fazla çıktı ile girdi arasındaki ilişkiyi birleştirerek bir tek etkinlik ölçütüne indirgemek karmaşı matematiksel işlemler gerektirmektedir (Şahin, 1999). Bu noktada VZA devreye girerek araştırmacıların işini kolaylaştırmaktadır. $\mathrm{Bu}$ analizde, değerlendirmeye tabi tutulan birimin performans1, değerlendirildiği karar birimleri içerisinde en iyi performans gösteren birimlerin oluşturduğu bir sınıra uzaklığı ile ölçülür (Şahin, 1999) ve bunun sonucunda bahsi geçen karar birimine göreli bir performans skoru atanır (Boles vd., 1995). Bu performans skoru atanırken etkinlik sınırının üzerinde bulunan karar değişkenleri verimli kabul edilir ve 1 skorunu alırlar; etkinlik sınırı üzerinde olmayanlar ise verimsiz kabul edilerek 1'den düşük skor alırlar (Laplante ve Paradi, 2015). Analizde karar birimlerinin verimli/verimsiz sayılmasını belirleyen kriterler aşağıdaki gibi sıralanmaktadır (Charnes vd., 1981):

a) Bir karar birimi için, herhangi bir girdiyi artırmadan ve diğer herhangi bir çıktıyı azaltmadan bir çıktıyı artırmak mümkünse, o karar birimi verimli değildir (Çıktı odaklılık).

b) Bir karar birimi için, diğer herhangi bir girdiyi artırmadan ve hiçbir çıktıyı azaltmadan bir girdiyi azaltmak mümkünse, o karar birimi verimli değildir (Girdi odaklılık).

Yukarıda bahsedilen kriterlerden hangisinin esas alınacağı, yapılan çalışmanın girdi veya çıktı odaklı olmasına bağlı olarak değişmektedir. Bir çalışmada girdi ya da çıktıya yönelik modeller kullanılması arasındaki fark şudur: "Girdiye yönelik modeller, belirli bir çıktı bileşimini en etkin bir şekilde üretebilmek amaciyla kullanılacak en uygun girdi bileşiminin nasil olması gerektiğini ortaya koyarken çıktıya yönelik modeller, belirli bir girdi bileşimi ile en fazla ne kadar çıktı bileşimi elde edilebileceğini ortaya koymaktadır" (Şahin, 1998). Yöntem olarak VZA'nın kullanıldığı bir çalışmada öncelikle, çalışmanın girdi odaklı mı yoksa çıktı odaklı mı olacağına karar verilmeli ve sonrasında, daha önce açılanan VRS ya da CRS modellerinden hangisinin benimsenmesinin çalışmaya daha uygun gideceğine karar verilmelidir. Eğer incelenen karar verme birimlerinin yönetsel kapasite girdilerini azaltarak verimliği artırmaya imkân tanıyor ise girdi odaklı; çıktıları artırarak verimliliği artırmaya imkân tanıyor ise çıktı odaklı VZA kullanılır (Narcı, 2012). Sağlık hizmetlerinde, yönetimsel kontrol çıktılardan ziyade girdiler üzerinde olduğu için sağlık hizmetleri alanında yapılan VZA çalışmaları, genellikle girdi odaklıdır (Kocaman vd.,2012; Ayanoğlu vd., 2010). Bu nedenle çalışmada, $A B$ döngüsündeki ülkelerin sağlık hizmetlerinin saf teknik verimliliklerini girdi odaklı VRS modeli kullanarak karşılaştırmak amaçlanmıştır.

\section{VERILLERIN ANALİİ}

Yöntem olarak VZA'nın kullanıldığı çalışmalarda, ayrık girdi ve çıktı değişkenlerine sahip karar verme birimlerinin VZA'nın sonuçlarına etkisinin 
azaltılabilmesi için kümeleme analizi uygulanabilir ve böylelikle karar verme birimlerinin kendi içlerinde homojen, aralarında heterojen olmaları sağlanabilir (Okursoy ve Özdemir, 2015). Bu bağlamda bu çalışmada, VZA uygulanmadan önce kümeleme analizi ile karar verme birimlerinin kendi içlerinde homojen olmaları sağlanmıştır.

Araştırmanın amacına uygun olarak toplanan veriler SPSS (Statistical Package for the Social Sciences) 20.0 ve STATISTICA 10.0 programları aracılığıla değerlendirilmiştir. Ülkelerin să̆lık göstergelerine göre kümelenmesinde hiyerarşik kümeleme yöntemlerinden Tam Bağlantı Yöntemi (Complete Linkage) kullanılmıştır. Tam Bağlantı kümeleme analizinde uzaklık ölçüsü olarak Öklit uzaklık ölçüsü kullanılmıştır. Ülkeler arası uzaklıklar hesaplanmadan ve kümeleme analizi yapılmadan önce sağlık göstergeleri verisi z standartlaştırma yöntemiyle standartlaştırılmıştır. Çünkü uzaklık ölçülerinin kullanıldığı kümeleme yöntemleri değişkenler arası farklılıklara çok duyarlıdır, genel bir kural olarak yaygınlığı fazla olan değişkenin etkisi de fazladır. Bu nedenle böyle durumlarda verilerin standartlaştırılması uygun olacaktır (Alpar, 2013). Küme sayısı ve küme üyelikleri belirlendikten sonra, oluşan kümelere ait verilerin ortalamaları tablo ve küme merkezleri profilleri grafiği ile incelenmiştir. Kümelere göre sağlık göstergelerinin ortalamaları arasında fark (kümelerin kendi içinde homojen, aralarında heterojen) olup olmadığını anlamak için iki ortalama arasındaki farkın önemlilik testinden (Independent Sample T Test) yararlanılmıştır.

VZA ise Microsoft Office Excel-Solver ile gerçekleştirilmiştir. Daha önce de belirtildiği gibi, sağlı hizmetlerinde yönetimsel kontrol çıktılardan ziyade girdiler üzerinde olduğundan ve bu çalışmada ülke sağl1k sistemlerinin saf teknik verimlilikleri karşılaştııılmak istendiğinden girdi odaklı VRS modeli kullanılmıştır.

\section{KISITLILIKLAR VE VARSAYIMLAR}

Çalışmada kullanılan veriler çoğunlukla, OECD Health at Glance: Europe 2016 State of Health in the EU Cycle isimli rapordan alınmıştır (http://www.oecd.org/health/health-at-a-glance-europe-23056088.htm) ve 2014 yılına aittir. Ancak bazı ülkelerin bazı verileri 2014 yılına ait değildir. Bu durumdaki ülkeler ve veriler için 2014 yılına en yakın yıllara ait veriler kullanılmıştır. Bahsi geçen raporda yer almayan bazı ülkelerin verileri ise; Organisation for Economic Co-operation and Development (OECD) Health Data (http://www.oecd.org/health/), World Health Organization (WHO) Global Health Observatory Data Repository (http://apps.who.int/gho/data/node.home) ve World Bank Health Data (http://databank. worldbank.org/data/reports.aspx?source=world-developmentindicators)'dan alınmış ve Tablo 2'nin altında dipnot olarak belirtilmiştir.

$\mathrm{Bu}$ kısıtlılıkların yanı sıra, çalışmanın temel yöntemi olan VZA'nın doğasından kaynaklanan bazı kısıtll1ıklar ve varsayımlar da söz konusudur. Bu kısıtlılıklar ve varsayımlar şunlardır:

$\checkmark \mathrm{Bu}$ çalışmada $\mathrm{AB}$ döngüsündeki ülkelerin, sadece sağl1k sistemlerinin verimlilik performansı boyutu ölçülmeye çalışılmıştır. Diğer faktörler sabit olmak 
koşulu ile seçilen temsili girdi ve çıktı değişkenleri ile analiz gerçekleştirilmiş olup çıkan sonuçların bu kısıtın dikkate alınmak suretiyle değerlendirilmesinde yarar vardir.

$\checkmark$ VZA'nın; kullanılan değişkenlerden, analizin girdi odaklı veya çıktı odaklı olmasından ya da ölçeğe göre sabit getirili veya değişken getirili olmasından etkilendiği göz önünde bulundurulmalıdır. Yani analizde kullanılan girdi ve çıktı değişkenlerinin veya modellerin ve varsayımların değiştirilmesi halinde $\mathrm{AB}$ döngüsündeki ülkelere ait etkinlik skorlarının değișebileceği unutulmamalıdır.

$\checkmark$ VZA'da karar verme birimlerinin etkinliği, etkinliği en iyi olan birimlerin göstermiş olduğu performansa göre şekillenen bir etkinlik sınırına olan uzaklıklarına göre değerlendirilmektedir. Bu sınırın genel kabul görmüş standart bir sınır olamayabileceği ortadadır.

\section{BULGULAR}

$\mathrm{Bu}$ çalışma kapsamında kullanılan sağlık göstergeleri ve açıklamaları Tablo 1'de sunulmuştur.

\begin{tabular}{|c|c|c|}
\hline & DEĞİŞKENLER & AÇIKLAMA \\
\hline \multirow{4}{*}{ 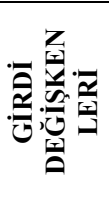 } & Hekim Sayıs1 & 1000 kişiye düşen hekim sayısı (1 yıl içinde) \\
\hline & Hemşire Sayısı & 1000 kişiye düşen hemşire sayısı (1 yıl içinde) \\
\hline & Yatak Sayıs1 & 1000 kişiye düşen yatak sayısı (1 yıl içinde) \\
\hline & Kişi Başı Sağlık Harcaması (KBSH) & $\begin{array}{l}\text { Yatırım harcamaları hariç, kişi başına düşen toplam } \\
\text { sağlık harcaması, satın alma gücü paritesine göre } \$ \\
\text { olarak ( } 1 \text { yıl içinde) }\end{array}$ \\
\hline \multirow{4}{*}{ 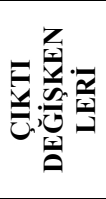 } & $\begin{array}{llll}\begin{array}{l}\text { Doğuşta } \\
\text { (DBYS) }\end{array} & \text { Beklenen } & \text { Yaşam } & \text { Süresi } \\
\end{array}$ & $\begin{array}{l}\text { Yeni doğan birinin doğumda beklediği ortalama yaşam } \\
\text { süresidir }\end{array}$ \\
\hline & Ortalama Yatış Süresi (OYS) (Tersi) $^{*}$ & Bir yılda yatılan ortalama gün sayısı \\
\hline & 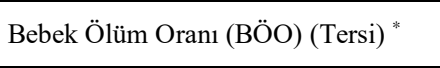 & $\begin{array}{l}1 \text { yaş altı ölen bebek sayısının } 1.000 \text { canlı doğan bebeğe } \\
\text { oranıdır ( } 1 \text { yıl içinde) }\end{array}$ \\
\hline & Ana Ölüm Oranı (AÖO) (Tersi) $^{*}$ & Her 1000 canlı doğumda anne ölüm oranı \\
\hline
\end{tabular}

*OYS, BÖO ve AÖO göstergelerinin düşük olması arzu edilen bir durum olduğundan, çalışmada bu göstergelerin tersi alınmıştır.

Çalışma kapsamına alınan ülkeler ve bu ülkelere ait sağlık göstergeleri ile ilgili veriler Tablo 2'de verilmiştir.

Tablo 2. Avrupa Birliği Döngüsündeki Ülkelerin Sağlık Göstergeleri

\begin{tabular}{|c|c|c|c|c|c|c|c|c|}
\hline Ülkeler & $\begin{array}{l}\text { Hekim } \\
\text { sayısı }^{1}\end{array}$ & $\begin{array}{c}\text { Hemşire } \\
\text { sayssı }^{2}\end{array}$ & $\begin{array}{l}\text { Yatak } \\
\text { sayısi }^{3}\end{array}$ & $\mathrm{KBSH}^{4}$ & DBYS $^{5}$ & OYS $^{6}$ & BÖO $^{7}$ & AÖO ${ }^{8}$ \\
\hline İspanya & 3,8 & 5,2 & 3,0 & 2965,8 & 83,3 & 7,40 & 2,8 & 5,0 \\
\hline İtalya & 3,9 & 6,2 & 3,3 & 3238,9 & 83,2 & 8,00 & 2,8 & 4,0 \\
\hline Fransa & 3,3 & 9,6 & 6,2 & 4508,1 & 82,8 & 10,10 & 3,5 & 9,0 \\
\hline İsveç & 4,1 & 11,2 & 2,5 & 5218,9 & 82,3 & 5,70 & 2,2 & 4,0 \\
\hline GKRK & 3,4 & 5,0 & 3,4 & 2062,4 & 80,1 & 6,40 & 2,2 & 7,0 \\
\hline Lüksemburg & 2,9 & 12,0 & 4,9 & 6812,1 & 82,2 & 8,80 & 3,1 & 10,0 \\
\hline Hollanda & 3,4 & 10,0 & 4,2 & 5201,7 & 81,8 & 6,40 & 3,6 & 7,0 \\
\hline Avusturya & 5,1 & 8,0 & 7,6 & 5038,9 & 81,7 & 8,20 & 3,0 & 4,0 \\
\hline Malta & 3,7 & 8,0 & 4,7 & 3071,6 & 81,9 & 7,90 & 5,7 & 9,0 \\
\hline Yunanistan & 6,3 & 3,2 & 4,2 & 2098,1 & 81,5 & 6,80 & 3,8 & 3,0 \\
\hline Belçika & 3,0 & 10,6 & 6,2 & 4391,6 & 81,4 & 7,80 & 3,4 & 7,0 \\
\hline İrlanda & 2,8 & 11,9 & 2,6 & 3801,1 & 81,4 & 6,00 & 3,7 & 8,0 \\
\hline Birleşik & 2,8 & 8,2 & 2,7 & 3376,9 & 81,4 & 7,10 & 3,9 & 9,0 \\
\hline
\end{tabular}


Mesut Teleş \& Cuma Çakmak \& Murat Konca / Avrupa Birliği Döngüsündeki Ülkelerin Sağlık Sistemleri

Performanslarının Karşılaştırılması

\begin{tabular}{|l|c|c|c|c|c|c|c|c|}
\hline Portekiz & 4,4 & 6,1 & 3,3 & 1570,4 & 81,3 & 8,90 & 2,9 & 10,0 \\
\hline Finlandiya & 3,0 & 14,1 & 4,5 & 3701,1 & 81,3 & 10,60 & 2,2 & 3,0 \\
\hline Almanya & 4,1 & 13,1 & 8,2 & 5182,1 & 81,2 & 9,00 & 3,2 & 6,0 \\
\hline Slovenya & 2,8 & 8,6 & 4,5 & 2697,7 & 81,2 & 6,90 & 1,8 & 9,0 \\
\hline Danimarka & 3,7 & 16,5 & 2,7 & 4782,1 & 80,7 & 4,30 & 4,0 & 7,0 \\
\hline Çek & 3,7 & 7,9 & 6,5 & 2146,3 & 78,9 & 9,40 & 2,4 & 4,0 \\
\hline Hirvatistan & 3,1 & 5,8 & 5,9 & 1652,1 & 77,9 & 8,80 & 5,0 & 9,0 \\
\hline Polonya & 2,3 & 5,2 & 6,6 & 2689,9 & 77,8 & 6,90 & 4,2 & 3,0 \\
\hline Estonya & 3,3 & 5,7 & 5,0 & 1668,3 & 77,4 & 7,60 & 2,7 & 9,0 \\
\hline Slovakya & 3,4 & 5,8 & 5,8 & 2179,1 & 77,0 & 7,30 & 5,8 & 6,0 \\
\hline Macaristan & 3,3 & 6,4 & 7,0 & 1826,7 & 76,0 & 9,50 & 4,5 & 16,0 \\
\hline Romanya & 2,7 & 6,2 & 6,7 & 1079,3 & 75,0 & 7,50 & 8,4 & 31,0 \\
\hline Litvanya & 4,3 & 7,6 & 7,2 & 1718,0 & 74,7 & 8,00 & 3,9 & 10,0 \\
\hline Bulgaristan & 4,0 & 4,4 & 7,1 & 1398,9 & 74,5 & 5,40 & 7,6 & 11,0 \\
\hline Letonya & 3,2 & 4,8 & 5,7 & 940,3 & 74,5 & 8,30 & 3,8 & 18,0 \\
\hline İsviçre & 4,1 & 17,6 & 4,6 & 6468,5 & 83,3 & 8,50 & 3,9 & 5,0 \\
\hline İzlanda & 3,6 & 15,3 & 3,2 & 3881,7 & 82,9 & 6,10 & 2,1 & 4,0 \\
\hline Norveç & 4,4 & 16,9 & 3,8 & 6346,6 & 82,2 & 6,00 & 2,4 & 5,0 \\
\hline Arnavutluk & 1,3 & 4,3 & 2,9 & 614,5 & 78,3 & 5,50 & 7,9 & 29,0 \\
\hline Türkiye & 1,8 & 1,9 & 2,7 & 1036,5 & 78,1 & 4,00 & 11,1 & 17,0 \\
\hline Karadağ & 2,2 & 5,1 & 3,9 & 888,2 & 76,6 & 8,50 & 4,6 & 7,0 \\
\hline Makedonya & 2,9 & 4,0 & 4,4 & 851,2 & 75,5 & 5,60 & 9,9 & 8,0 \\
\hline Sirbistan & 3,1 & 5,9 & 5,5 & 1312,2 & 75,4 & 10,00 & 5,7 & 17,0 \\
\hline Ortalama & $\mathbf{3 , 4}$ & $\mathbf{8 , 3}$ & $\mathbf{4 , 8}$ & $\mathbf{3 0 1 1 , 6}$ & $\mathbf{7 9 , 6}$ & $\mathbf{7 , 5}$ & $\mathbf{4 , 3}$ & $\mathbf{9 , 2}$ \\
\hline
\end{tabular}

${ }^{1}$ Hekim Sayısı verisi içerisinde; Finlandiya, Danimarka, Çek Cumhuriyeti ve Arnavutluk verileri 2013 yılı verisidir; Almanya'nın verisi Dünya Bankasından alınmıştır.

${ }^{2}$ Hemşire sayısı verisi içerisinde; Finlandiya'nın verisi 2012 yılına aittir; İsveç ve Danimarka'nın verileri 2013 yılına aittir; Arnavutluk'un verisi Dünya Sağlık Örgütünün 2013 yılı raporundan elde edilmiştir. http://www.euro.who.int/ data/assets/pdf file/0019/290440/Core-Health-Indicators-European-2015-humanresources-health.pdf?ua $=1$

${ }^{3}$ Yatak sayısı verisi içerisinde, İtalya'nın verisi 2013 yılına aittir; Hollanda'nın verisi OECD Health Data' dan elde edilmiş ve 2013 yılına aittir; Arnavutluk'un verisi ise 2012 yılına ait ve Dünya Bankasından elde edilmişstir.

${ }^{4}$ Kişi Başı Toplam Sağlık Harcaması verileri tümüyle Dünya Bankasından alınmıştır.

${ }^{5}$ Doğuşta beklenen yaşam süresi verisi içerisinde; GKRK, Lüksemburg, Malta, İzlanda, Karadağ ülkelerine ait veriler Dünya Bankasından elde edilmiştir.

${ }^{6}$ Ortalama Yatış Süresi verisi içerisinde; Yunanistan verisi 2011, Hollanda verisi 2012, Belçika ve Fransa verileri 2013 yılına aittir. Bununla birlikte Arnavutluk’un verisi 2013 yılına aittir ve Dünya Sağlık Örgütünden alınmıştır. https://gateway.euro.who.int/en/indicators/hfa 540-6100-average-length-of-stay-all-hospitals/

${ }^{7}$ Bebek Ölüm oranı verisi içerisinde, İsveç ve İzlanda'nın verisi OECD Health Data' dan alınmıştır; Kıbrıs, Malta ve Karadağ' 1 verileri OECD Health at Glance: Europe 2016 State of Health in the EU Cycle isimli rapordan elde edilmiş olup bahsi geçen ülkelere ait Bebek ölüm oranı verisi; 2012,2013 ve 2014 yıllarının ortalamasıdır.

${ }^{8}$ Anne Ölüm Oranı verisi, 2014 Dünya Bankası veri tabanından alınmıştır.

Avrupa Birliği döngüsündeki ülkelerin sağl1k göstergelerine göre tam bağlantı yöntemi ile nasıl kümelendiği Şekil 1'de ağaç diyagramı ile gösterilmiş̧ir. 
Şekil 1. AB Döngüsündeki Ülkelerin Kümeleme Analizi Sonuçlarının Ağaç Diyagramı İle Gösterimi

Tam Bağlantı Yöntemi

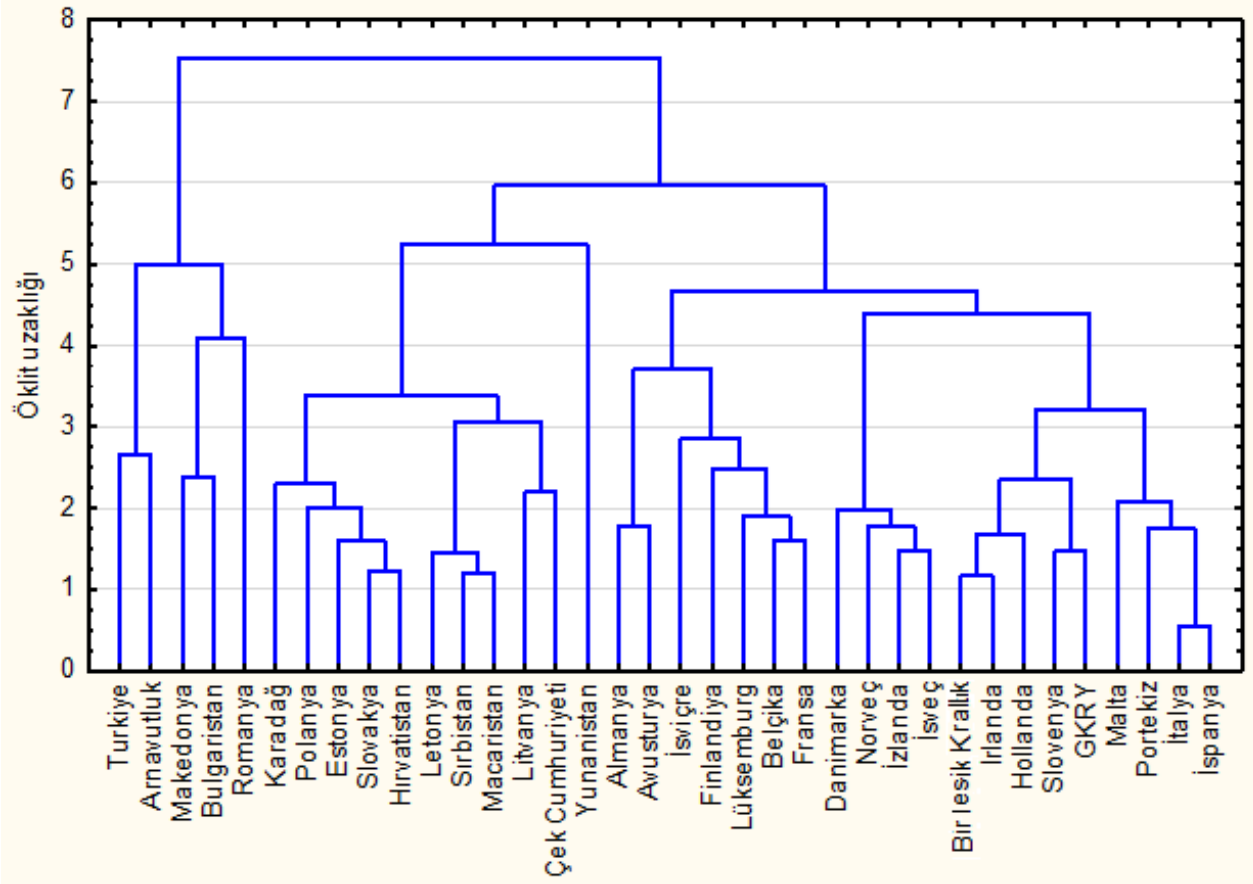

Şekil 1'e göre AB döngüsündeki ülkelerin 2, 3, 4 hatta 5 ve daha üzeri kümede toplanabileceğini söyleyebiliriz. Ancak, VZA analizi için karar merkezlerinin belirli bir sayı ve üstünde olması gerektiğinden, Şekil 1'e göre AB döngüsündeki ülkelerin bu çalışmanın amacı kapsamında kabaca 2 kümede toplanabileceğini söyleyebiliriz. Olası kümeler ve kümelere ait ülkeler Tablo 3 'te verilmiştir. Bu sonuçlara göre, Türkiye'nin de içinde bulunduğu birinci küme 16 ülkeden, ikinci küme ise 20 ülkeden oluşmaktadır.

Tablo 3. Sağlık Göstergelerine Göre Olası Kümeler

\begin{tabular}{|c|c|c|}
\hline Kümeler & Ülkeler & $\begin{array}{c}\text { Kümelerdeki Gözlem } \\
\text { Sayısı }\end{array}$ \\
\hline 1 & $\begin{array}{l}\text { Türkiye, Arnavutluk, Makedonya, Bulgaristan, Romanya, } \\
\text { Karadağ, Polonya, Estonya, Slovakya, Hırvatistan, Letonya, } \\
\text { Sirbistan, Macaristan, Litvanya, Çek Cumhuriyeti, } \\
\text { Yunanistan }\end{array}$ & 16 \\
\hline 2 & $\begin{array}{l}\text { Almanya, Avusturya, İsviçre, Finlandiya, Lüksemburg, } \\
\text { Belçika, Fransa, Danimarka, Norveç, İzlanda, İsveç, Birleşik } \\
\text { Krallık, İrlanda, Hollanda, Slovenya, GKRK, Malta, } \\
\text { Portekiz, İtalya, İspanya }\end{array}$ & 20 \\
\hline & Toplam & 36 \\
\hline
\end{tabular}

Oluşan kümelere ait sağlık göstergelerinin ortalamaları Tablo 4'te, küme ortalamalarını karşılaştırmalı olarak daha kolay inceleyebilmek için sağlık göstergelerinin z standart değerleri esas alınarak hesaplanan küme merkezlerinin profil grafiği ise Grafik 1'de verilmiştir. Kümeleme analizi sonrasında oluşan 
kümelerin kendi içinde homojen, aralarında ise heterojen olması beklenmekteydi. Bu çalışmada kullanılan 8 sağlık göstergesinden 2'si (hekim sayısı ve ortalama yatış süresi) hariç, diğer 6 sağlı göstergelerinin (hemşire sayısı, yatak sayısı, $\mathrm{KBSH}, \mathrm{DBYS}, \mathrm{BÖO}$ ve AÖO) ortalaması kümelere göre istatistiksel olarak anlamlı fark gösterdiğinden $(\mathrm{p}<0,05)$, küme 1 ve küme 2'nin kendi içinde homojen, aralarında ise heterojen olduğunu söyleyebiliriz. Tablo 4 ve Grafik 1 birlikte değerlendirildiğinde, Türkiye'nin de içinde bulunduğu küme 1'de hekim ve hemşire sayısının daha az, yatak sayısının daha fazla, kişi başı sağlık harcaması ve doğuşta beklenen yaşam süresinin daha düşük, bebek ölüm oranı ve ana ölüm oranının ise daha yüksek olduğu görülmektedir.

Tablo 4. Kümelere Göre Sağlı Göstergeleri Ortalaması

\begin{tabular}{|c|c|c|c|c|}
\hline Sağlık Göstergeleri & $\begin{array}{c}\text { Küme } 1(\mathrm{n}=16) \\
{\text { Ortalama } \pm \mathbf{S S}^{1}}\end{array}$ & $\begin{array}{c}\text { Küme } 2(\mathrm{n}=\mathbf{2 0}) \\
\text { Ortalama } \pm \mathrm{SS}^{*}\end{array}$ & $\mathbf{t}$ & $\mathbf{P}^{* * *}$ \\
\hline Hekim sayısı & $3,18 \pm 1,14$ & $3,61 \pm 0,63$ & $-1,14$ & 0,159 \\
\hline Hemşire sayısı & $5,26 \pm 1,52$ & $10,71 \pm 3,92$ & $-5,69$ & $<0,001$ \\
\hline Yatak sayısı & $5,44 \pm 1,46$ & $4,31 \pm 1,64$ & 2,17 & $\mathbf{0 , 0 3 7}$ \\
\hline $\mathrm{KBSH}$ & $1506,23 \pm 588,08$ & $4215,92 \pm 1440,04$ & $-7,06$ & $<0,001$ \\
\hline DBYS & $76,82 \pm 1,93$ & $81,88 \pm 0,89$ & $-10,48$ & $<0,001$ \\
\hline OYS & $7,44 \pm 1,68$ & $7,50 \pm 1,58$ & $-0,11$ & 0,912 \\
\hline BÖO & $5,71 \pm 2,56$ & $3,12 \pm 0,90$ & 3,85 & 0,001 \\
\hline AÖO & $12,38 \pm 8,47$ & $6,60 \pm 2,26$ & 2,65 & $\mathbf{0 , 0 1 7}$ \\
\hline
\end{tabular}

Grafik 1. Sağlık Göstergelerine Göre Oluşan Küme Merkezleri Profilleri

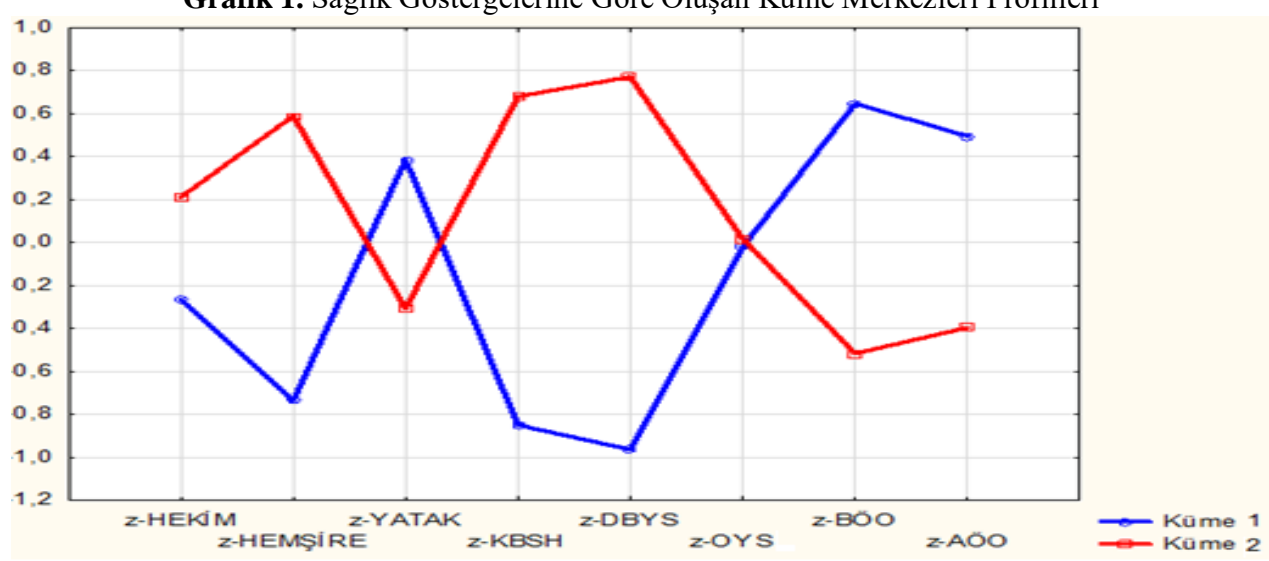

Çalışma kapsamında uygulanan kümeleme analizi sonucu ülkeler iki kümeye ayrılmış ve bu iki kümeye, öncelikle ayrı ayrı girdi odaklı ölçeğe göre değişken getiri modeline göre VZA uygulanmıştır. Daha sonra, $A B$ döngüsünde ülkelerin tamamına girdi odaklı ölçeğe ve değişken getiri modeline göre VZA uygulanmıştır.

Girdi Odakıı ve Değişken Getiri Modeline Göre Birinci Kümedeki Ülkelerin Karşılaştırılması

Birinci kümede yer alan ülkelerin sağl1k sistemlerinin etkinlik skorları ve verimsiz sağlı sistemine sahip ülkeler için referans gösterilen verimli ülkeler 
Tablo 5'te sunulmaktadır. Buna göre, birinci kümede yer alan 16 ülkenin 9'unun $(\% 56,25)$ sağlık sistemi verimlidir ve bu kümede yer alan ülkelerin etkinlik skorları ortalamasi $0,86 \pm 0,16$ 'dir.

Tablo 5. Birinci Kümede Yer Alan Ülkelerin Girdi Yönelimli VRS Analizi Sonuçları

\begin{tabular}{|c|c|c|c|c|c|c|c|}
\hline Ülkeler & Etkinlik & & msiz Olan I & Ikeler İçin & Referans ÜI & |keler & \\
\hline Yunanistan & 1,0000 & & & & & & \\
\hline Çek Cumhuriyeti & 1,0000 & & & & & & \\
\hline Hurvatistan & 0,7282 & Çek & Polonya & Estonya & Arnavutluk & Türkiye & Karada \\
\hline Polonya & 1,0000 & & & & & & \\
\hline Estonya & 1,0000 & & & & & & \\
\hline Slovakya & 0,6979 & Yunanistan & Polonya & Türkiye & Karadağ & & \\
\hline Macaristan & 0,6839 & Estonya & Arnavutlu & Türkiye & & & \\
\hline Romanya & 0,6318 & Arnavutluk & Türkiye & & & & \\
\hline Litvanya & 0,6406 & Estonya & Letonya & Arnavutlu & Türkiye & Karada & \\
\hline Bulgaristan & 0,6987 & Yunanistan & Türkiye & Karadağ & Makedony & & \\
\hline Letonya & 1,0000 & & & & & & \\
\hline Arnavutluk & 1,0000 & & & & & & \\
\hline Türkiye & 1,0000 & & & & & & \\
\hline Karadağ & 1,0000 & & & & & & \\
\hline Makedonya & 1,0000 & & & & & & \\
\hline Sirbistan & 0,6805 & Estonya & Letonya & Arnavutlu & Türkiye & Karada & \\
\hline
\end{tabular}

Tablo 5'ten ülkelerin sağlık sistemlerinin etkinlik skorları baz alınarak ülkelerin sağlık sistemlerinin etkinlik durumunu gösteren Grafik 2 oluşturulmuştur. Grafik 2 incelendiğinde birinci kümede yer alan; Slovakya, Macaristan, Romanya, Litvanya ve Bulgaristan'ın düşük etkinlik skorlarına sahip oldukları görülmektedir. $\mathrm{Bu}$ ülkelerin bu çalışmada girdi olarak kullanılan yatak sayısı değişkeninde, ikinci kümedeki diğer ülkelere nazaran daha yüksek sayıya sahip olması ve bu çalışmada çıktı olarak kullanılan doğuşta beklenen yaşam süresi değişkeninde daha düşük sonuçlara sahip olması, düşük etkinlik skorlarının sebepleri olarak gösterilebilir.

Grafik 2. Birinci Kümedeki Ülkelerin Verimlilik Skorlarının Sütun Grafiği İle Sunumu

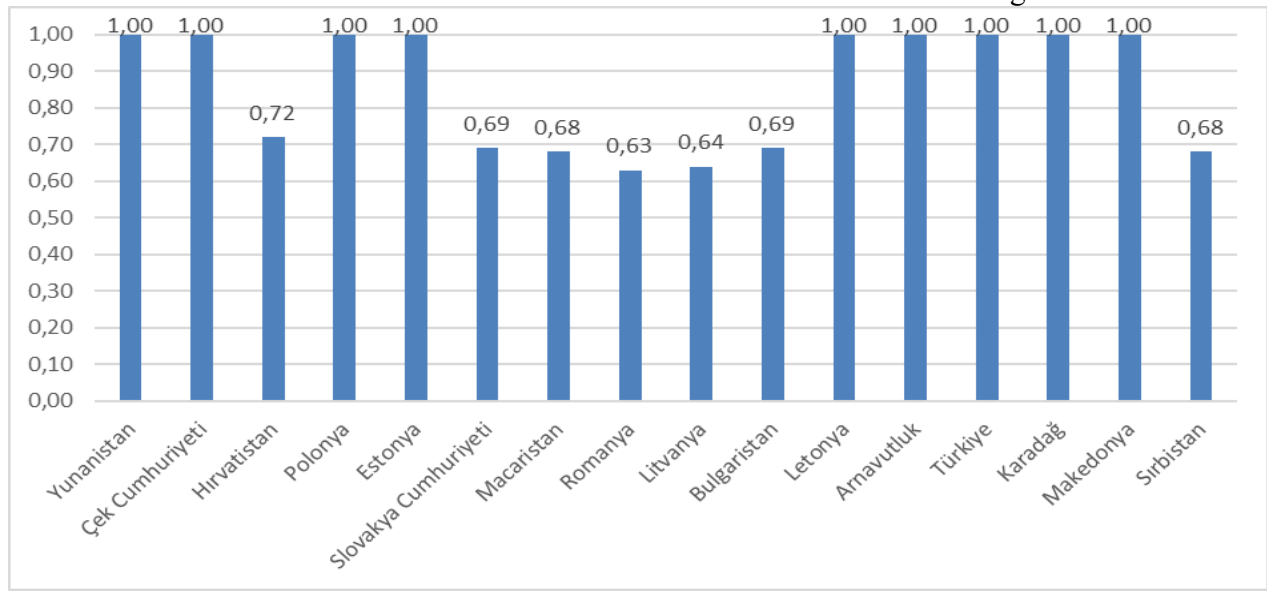


Grafik 3'te birinci kümedeki ülkelerden verimli olanların verimsiz olanlara referans olma sayıları gösterilmektedir. Buna göre, Türkiye bu kümede en çok referans olan ülkedir. Buradan Türkiye'nin sağlık göstergelerinin, bu çalışmada kullanılan girdiler ve çıktılar bakımından bu kümede verimsiz çıkan ülkelerinkine benzer sağlık göstergelerine sahip olduğu ve bu yüzden verimli çıkan diğer ülkelere nispeten daha çok referans gösterildiği yorumu yapılabilir.

Grafik 3. Birinci Kümedeki Ülkelerden Verimli Olanların Verimsiz Olanlara Referans Olma Sayılarının Sütun Grafik İle Sunumu

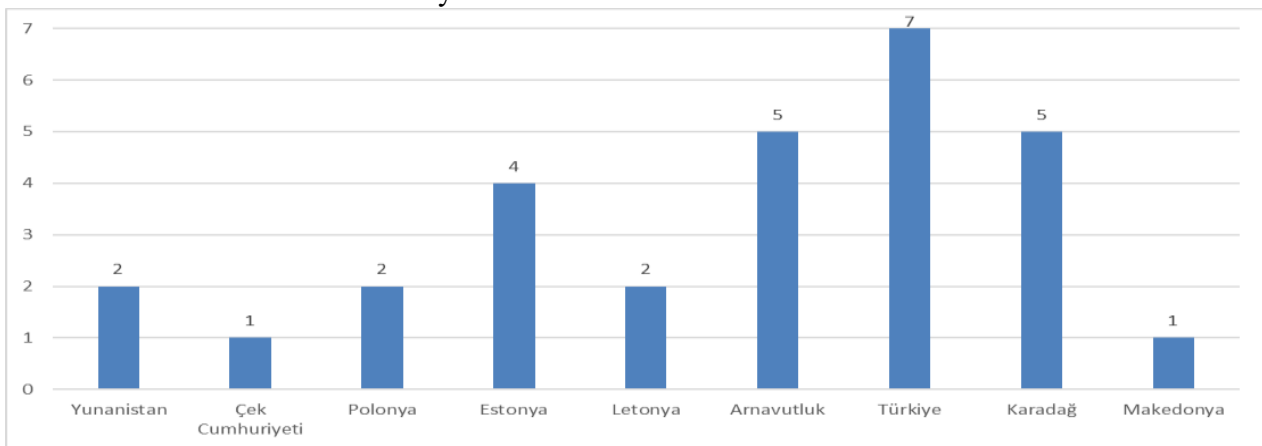

\section{Ülkelerin Karşılaştırılması}

Girdi Odaklı ve Değişken Getiri Modeline Göre İkinci Kümedeki

İkinci kümede yer alan ülkelerin sağlık sistemlerinin etkinlik skorları ve verimsiz sağlik sistemine sahip ülkeler için referans gösterilen verimli ülkeler Tablo 6'da sunulmaktadır. Buna göre, ikinci kümede yer alan 20 ülkenin 13'ünün (\% 65) sağlık sistemi verimlidir ve bu kümede yer alan ülkelerin etkinlik skorları ortalamasi $0,94 \pm 0,09$ 'dur.

Tablo 6. İkinci Kümede Yer Alan Ülkelerin Girdi Yönelimli VRS Analizi Sonuçları

\begin{tabular}{|c|c|c|c|c|c|c|}
\hline Ülkeler & Etkinlik & \multicolumn{5}{|c|}{ Verimsiz Olan Ülkeler İçin Referans Ülkeler } \\
\hline İspanya & 1,0000 & & & & & \\
\hline İtalya & 1,0000 & & & & & \\
\hline Fransa & 1,0000 & & & & & \\
\hline İsveç & 1,0000 & & & & & \\
\hline GKRK & 1,0000 & & & & & \\
\hline Lüksemburg & 1,0000 & & & & & \\
\hline Hollanda & 0,9241 & İspanya & GKRK & İrlanda & Birleşik & \\
\hline Avusturya & 0,7750 & İtalya & & & & \\
\hline Malta & 0,8822 & İspanya & GKRK & Portekiz & Slovenya & \\
\hline Belçika & 0,9426 & Lüksembur & İrlanda & Birleşik & Finlandiya & Sloveny \\
\hline İrlanda & 1,0000 & & & & & \\
\hline Birleşik & 1,0000 & & & & & \\
\hline Portekiz & 1,0000 & & & & & \\
\hline Finlandiya & 1,0000 & & & & & \\
\hline Almanya & 0,7086 & GKRK & Birleşik & Finlandiya & & \\
\hline Slovenva & 1.0000 & & & & & \\
\hline Danimarka & 1,0000 & & & & & \\
\hline İsviçre & 0,9268 & İspanya & & & & \\
\hline İzlanda & 1,0000 & & & & & \\
\hline Norveç & 0,7797 & İsveç & İrlanda & Slovenya & Danimarka & İzlanda \\
\hline
\end{tabular}


Tablo 6'daki etkinlik skorları kullanılarak ülkelerin sağlı sistemlerinin etkinlik durumunu gösteren Grafik 4 elde edilmiştir. Grafik 4 incelendiğinde benzer sosyo-ekonomik şartlara sahip olarak düşünülebilecek Almanya ve Avusturya'nın düşük etkinlik skorlarına sahip oldukları görülmektedir. Bu çalışma kapsamında kullanılan veri seti incelendiğinde, özellikle hekim ve yatak sayısı ile kişi başına düşen sağlık harcaması girdilerinin, bahsi geçen iki ülkede nispeten daha yüksek olduğu görülmektedir ve bu durum bu iki ülkenin düşük etkinlik skoruna sahip olmasının sebebi olarak düşünülmektedir.

Grafik 4. İkinci Kümedeki Ülkelerin Verimlilik Skorlarının Sütun Grafiği İle Sunumu

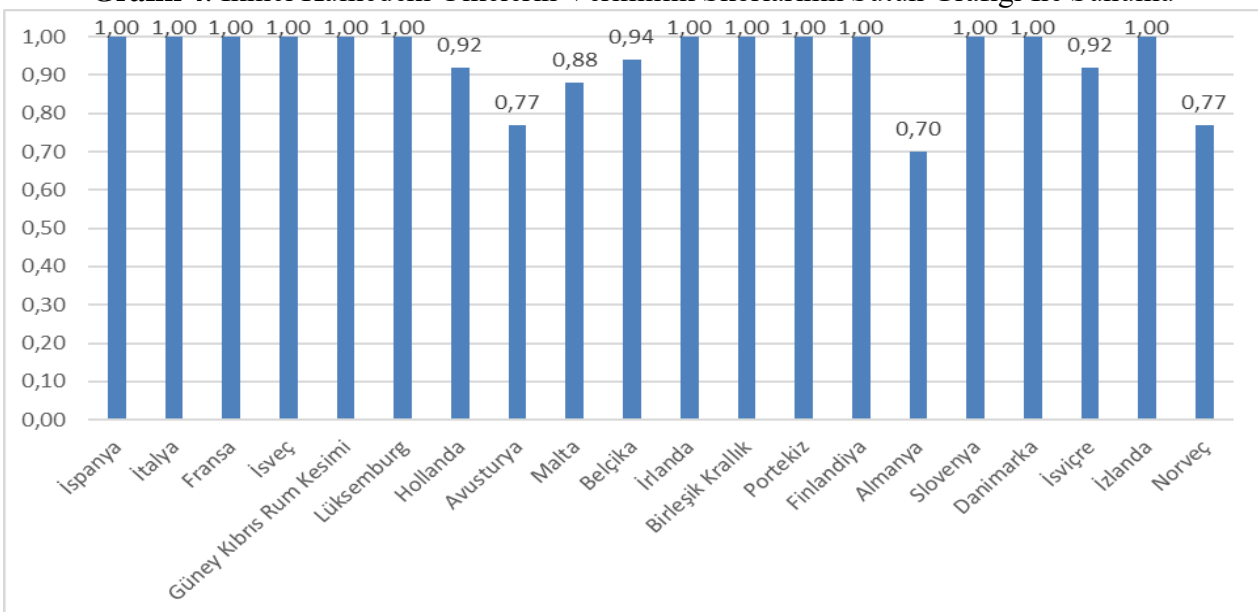

Grafik 5 'te ikinci kümedeki ülkelerden verimli olanların verimsiz olanlara referans olma sayıları gösterilmektedir. Referans gösterilen ülkeler referans gruplarına, verimsiz karar birimleriyle yakın özelliklere sahip olmaları sebebiyle dâhil edilmektedirler. Grafik 5'e göre, Fransa etkin bir sağlık sistemine sahip olmasına rağmen ikinci kümede yer alan hiçbir ülkeye referans olamazken; İspanya, GKRK, İrlanda, Birleşik Krallık ve Slovenya bu kümede en çok referans olan ülkelerdir.

Grafik 5. İkinci Kümedeki Ülkelerden Verimli Olanların Verimsiz Olanlara Referans Olma Sayılarının Sütun Grafik İle Sunumu

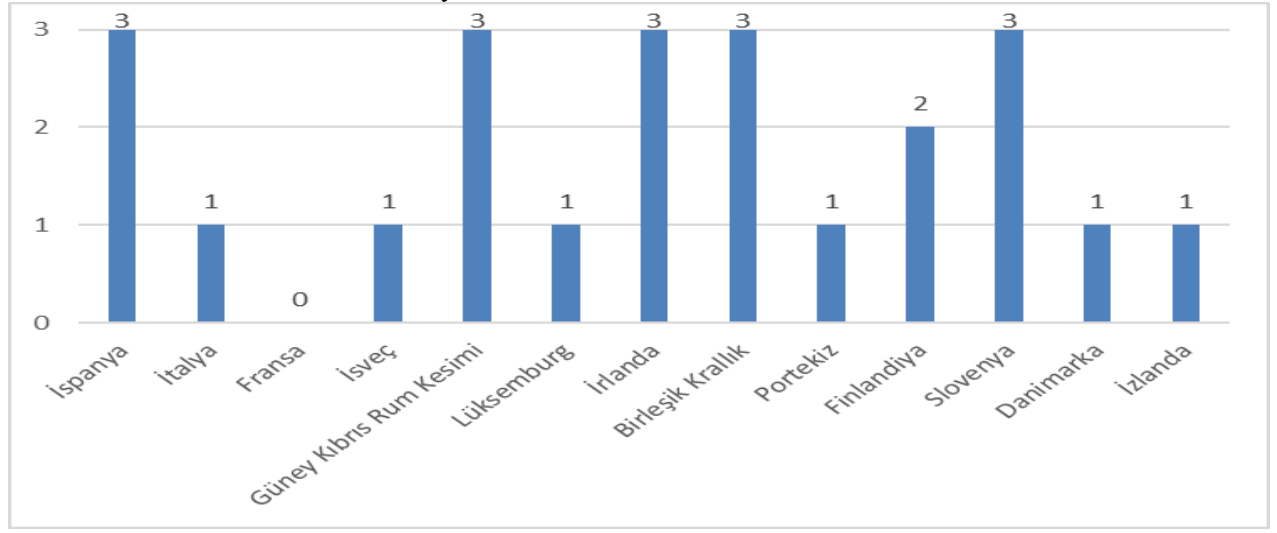


Mesut Teleş \& Cuma Çakmak \& Murat Konca / Avrupa Birliği Döngüsündeki Ülkelerin Sağllk Sistemleri Performanslarının Karşılaştırılması

\section{Girdi Odaklı ve Değişken Getiri Modeline Göre AB Döngüsündeki Ülkelerin Tamamının Karşılaştırılması}

Çalışma kapsamında $\mathrm{AB}$ döngüsündeki tüm ülkelerin sağlık sistemlerinin etkinlik skorları, herhangi bir kümelemeye tabi tutulmadan da karşılaştırılmıştır. Tablo 7'de, bu karşılaştırma sonucunda ortaya çıkan verimli ve verimsiz ülkeler, bu ülkelerin etkinlik skorları ve verimsiz olan ülkeler için referans gösterilen verimli ülkeler sunulmaktadır. Buna göre, toplam 36 ülkenin 21 'inin $(\% 58,33)$ sağlık sistemi verimlidir ve bu kümede yer alan ülkelerin etkinlik skorları ortalaması $0,89 \pm 0,14$ 'tür.

Tablo 7. AB Döngüsündeki Ülkelerin Tamamının Yer Aldığı Girdi Yönelimli

VRS Analizi Sonuçları

\begin{tabular}{|c|c|c|c|c|c|c|c|}
\hline Ülkeler & Etkinlik Skoru & \multicolumn{6}{|c|}{ Verimsiz Olan Ülkeler İçin Referans Ülkeler } \\
\hline İspanya & 1,0000 & & & & & & \\
\hline İtalya & 1,0000 & & & & & & \\
\hline Fransa & 1,0000 & & & & & & \\
\hline İsveç & 1,0000 & & & & & & \\
\hline GKRK & 1,0000 & & & & & & \\
\hline Lüksemburg & 1,0000 & & & & & & \\
\hline Hollanda & 0,8876 & İspanya & Lüksemburg & İrlanda & Arnavutluk & & \\
\hline Avusturya & 0,6899 & İspanya & İtalya & GKRK & Yunanistan & Polonya & \\
\hline Malta & 0,8288 & İspanya & Fransa & Arnavutluk & & & \\
\hline Yunanistan & 1,0000 & & & & & & \\
\hline Belçika & 0,9128 & İspanya & Fransa & Lüksemburg & Finlandiya & İzlanda & Arnavutluk \\
\hline İrlanda & 1,0000 & İspanya & Lüksemburg & İrlanda & İzlanda & & \\
\hline Birleşik Krallık & 1,0000 & & & & & & \\
\hline Portekiz & 1,0000 & & & & & & \\
\hline Finlandiya & 1,0000 & & & & & & \\
\hline Almanya & 0,6643 & İspanya & Lüksemburg & Finlandiya & Slovenya & Arnavutluk & \\
\hline Slovenya & 1,0000 & & & & & & \\
\hline Danimarka & 1,0000 & & & & & & \\
\hline Çek Cumhuriyeti & 1,0000 & & & & & & \\
\hline Hirvatistan & 0,6920 & GKRK & Yunanistan & Polonya & Arnavutluk & Türkiye & Karadağ \\
\hline Polonya & 1,0000 & & & & & & \\
\hline Estonya & 0,9566 & GKRK & Slovenya & Letonya & Karadağ & & \\
\hline Slovakya & 0,6902 & Yunanistan & Finlandiya & Polonya & Türkiye & Karada $\breve{g}$ & \\
\hline Macaristan & 0,6302 & GKRK & Letonya & Arnavutluk & Türkiye & & \\
\hline Romanya & 0,6318 & Arnavutluk & Türkiye & & & & \\
\hline Litvanya & 0,6237 & GKRK & Letonya & Arnavutluk & Türkiye & Karadă̆ & \\
\hline Bulgaristan & 0,6987 & Yunanistan & Türkiye & Karada $\breve{g}$ & Makedonya & & \\
\hline Letonya & 1,0000 & & & & & & \\
\hline İsviçre & 0,9268 & İspanya & & & & & \\
\hline İzlanda & 1,0000 & & & & & & \\
\hline Norveç & 0,7763 & İsveç & İrlanda & İzlanda & Arnavutluk & & \\
\hline Arnavutluk & 1,0000 & & & & & & \\
\hline Türkiye & 1,0000 & & & & & & \\
\hline Karadağ & 1,0000 & & & & & & \\
\hline Makedonya & 1,0000 & & & & & & \\
\hline Sirbistan & 0,6723 & GKRK & Letonya & Arnavutluk & Türkiye & Karadağ & \\
\hline
\end{tabular}


Tablo 7'den ülkelerin sağlık sistemlerinin etkinlik skorları alınarak Grafik 6 oluşturulmuştur. Grafik 6 incelendiğinde, herhangi bir kümeleme söz konusu olmadığında, yani $\mathrm{AB}$ döngüsünde bulunan tüm ülkeler tek bir kümede değerlendirildiğinde; Macaristan, Romanya ve Litvanya'nın en düşük etkinlik skorlarına sahip ülkeler olduğu ve bahsi geçen ülkelerin, kümeleme söz konusu olduğunda da bulundukları kümedeki en düşük etkinlik skorlarına sahip ülkeler olduğu görülmektedir. Bu ülkelerin kümeleme analizi sonucunda yer aldıkları kümede (1. Küme) verimsiz çıkma sebepleri olarak sayılan gerekçeler, tüm ülkelerin dahil edildiği analizde de düşük etkinlik skorlarına sahip olmalarına zemin hazırlamaktadır.

Grafik 6. AB Döngüsündeki Ülkelerin Tamamının Verimlilik Skorlarının Sütun Grafiği İle Sunumu

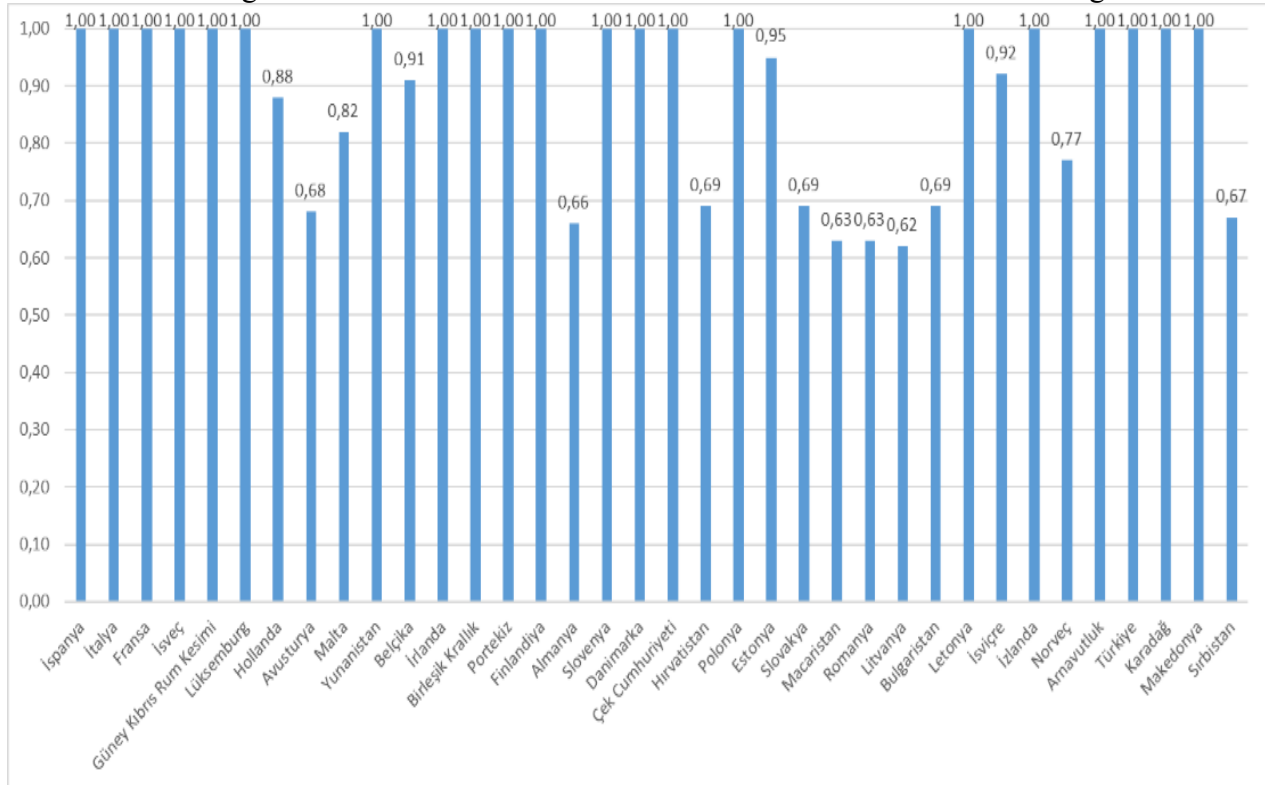

Grafik 7'de $\mathrm{AB}$ döngüsünde bulunan tüm ülkelerin yer aldığı analiz sonucunda verimli sağlık sistemine sahip olan ülkelerin verimsiz olanlara referans olma sayıları gösterilmektedir. Buna göre, Arnavutluk en çok referans gösterilen ülkedir. Arnavutluk'a ait girdi değişkenleri incelendiğinde, bu ülkenin girdi değişkenlerinin diğerlerine göre çok düşük seviyelerde olduğu görülmektedir. Bu durum en çok referans gösterilen ülkenin Arnavutluk olmasına sebep olarak gösterilebilir. Diğer taraftan $\mathrm{AB}$ döngüsünde bulunan tüm ülkeler karşılaştırıldığında; Birleşik Krallık, Portekiz, Danimarka ve Çek Cumhuriyeti'nin, verimli sağlık sistemlerine sahip olmalarına rağmen hiç referans gösterilmediği anlaşılmaktadır. 
Grafik 7. AB Döngüsündeki Ülkelerin Tamamının Yer Aldığı Analizde Verimli Olanların Verimsiz Olanlara Referans Olma Sayılarının Sütun Grafik İle Sunumu

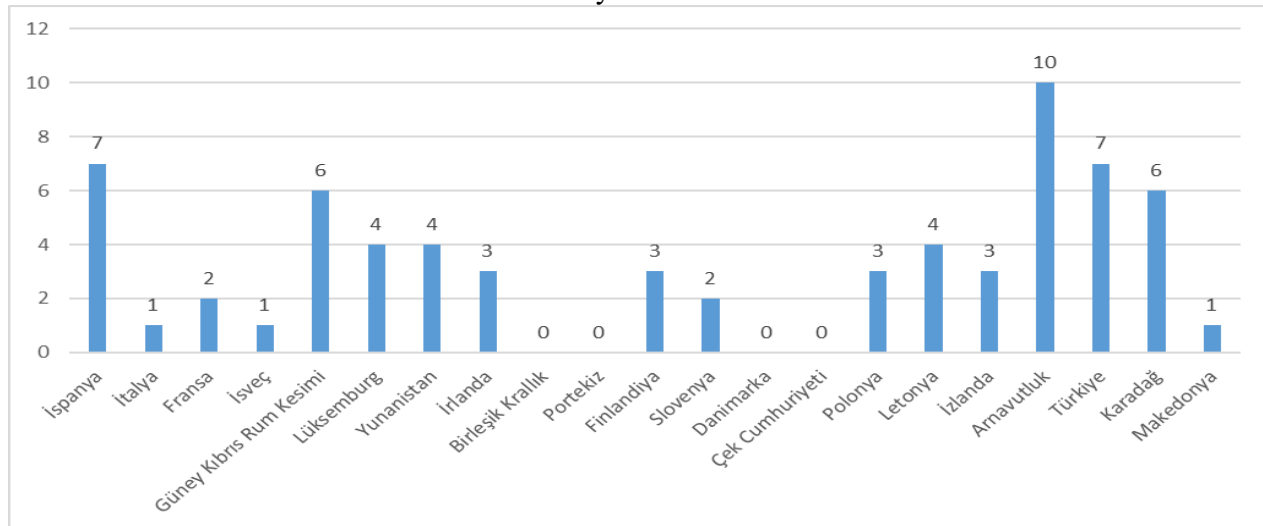

Çalışmada, $\mathrm{AB}$ döngüsündeki ülkelerin sağlık sistemlerinin verimlilik durumlarının, kümeleme olduğunda ve olmadığında değişip değişmediği incelendiğinde, Estonya dışındaki ülkelerin verimlilik durumunda herhangi bir değişimin olmadığı tespit edilmiştir. Estonya, kümeleme olduğunda verimli iken kümeleme olmadığında verimsizdir.

\section{TARTIŞMA}

Verimlilik konusu, birçok ülkenin sağlık sistemi ile ilgili tartışmaların merkezinde yer almaktadır. Her ne kadar sağlık sistemleri ülkeler için kâr amacının güdüldüğü ya da daha genel bir ifade ile finansal göstergelerin diğer göstergelere üstünlüğünün olduğu sistemler arasında sayılmasa da, her geçen gün artan sağlık harcamaları ve bunun yarattığı baskı verimlilik tartışmalarını, ister istemez ülkelerin gündemine taşımaktadır. Bu sebeplerden bu çalışmada, $\mathrm{AB}$ döngüsündeki ülkelerin sağlık sistemlerinin verimliliklerinin karşılaştırılması amaçlanmıştır.

$\mathrm{Bu}$ çalışmanın da temel yöntemi olan VZA'da karar verme birimlerinin etkinlikleri değerlendirilirken, bu birimlerin genellikle benzer yani homojen olması istenir. $\mathrm{Bu}$ nedenle, çalışma kapsamında $\mathrm{AB}$ döngüsündeki ülkeler hekim sayısı, hemşire sayıs1, yatak sayısı, KBSH, DBYS, OYS, BÖO ve AÖO sağlık göstergelerine göre kümeleme analizi ile değerlendirilmiş ve ülkelerin 2 ayrı kümede toplanabileceği sonucuna varılmıştır. Çalışmada, Türkiye'nin de içinde bulunduğu küme 16 ülkeden, diğer küme ise 20 ülkeden oluşmuştur. Lorcu (2008)'nun AB'ye üye 27 ülke ve AB'ye aday Türkiye'nin dahil olduğu 28 ülkeyi karar verme birimi olarak kullandığı bir çalışmada, GSYİH'dan sağlığa ayrılan pay, kişi başına düşen sağlık harcamaları, beş yaş altı çocuk ölüm hızı, yaşam beklentisi ve okul yaşam beklentisi değişkenlerini kullanarak yaptığı kümeleme analizi sonucunda ülkelerin 4 kümede toplanacağına karar verilmiş ve Türkiye'nin de içinde bulunduğu küme 11 ülkeden oluşmuştur. Bu çalışmadan farklı olarak, Lorcu (2008)'nun çalışmasında Türkiye'nin içinde bulunduğu kümede GKRK de yer almış, benzer olarak ise 11 ülkenin 10’u (Çek Cumhuriyeti, Estonya, Macaristan, Litvanya, Letonya, Polonya, Slovakya, Bulgaristan ve Romanya) Türkiye ile birlikte aynı kümede yer almıştır. İki çalışma birlikte değerlendirildiğinde, küme 
sayısı ve üyelikleri arasındaki bu farklılıklar, analize dahil edilen ülke sayıları ile kullanılan girdi ve çıktıların benzer olmamasından kaynaklanabileceği gibi kullanılan kümeleme analizi yöntemlerinin aynı olmamasından da kaynaklanmış olabilir.

Çalışmada VZA, hem kümelere göre hem de kümeleme olmadan ülkelerin tamamına uygulanmıştır. Analiz sonucunda verimsiz sağlık sistemine sahip olduğu görülen ülkelere referans olabilecek ülkeler belirlenmiştir. Çalışmada kümeleme analizinin olmadığı, yani tüm ülkelerin karşılaştırıldığ VZA sonuçları ile kümeleme analizi sonucu oluşan kümelere VZA'nın uygulanması ile elde edilen sonuçlar arasında fark olup olmadığına bakılmış, bir ülke (Estonya) dışında diğer tüm ülkelerin sağlık sistemlerinin verimliliği, kümeleme olduğu ve olmadığ durumlarda aynı bulunmuştur. Lorcu (2008)'nun çalışmasında ise kümeleme olduğunda verimli bulunan Bulgaristan, kümeleme olmadığında verimsiz bulunmuştur. Aynı çalışmada kümeleme olduğunda verimsiz bulunan Polonya ve Türkiye, kümeleme olmadığında verimli bulunmuştur. Bu çalışmayla Lorcu (2008)'nun çalışması arasında tutarlılık olmamasının nedenlerinden biri olarak, bu çalışmada kümeleme olduğu ve olmadığ 1 durumlar için aynı girdi ve çıktılar kullanılırken, Lorcu (2008)'nun çalışmasında kümeleme olduğunda ve olmadığında farklı sayılarda girdi ve çıktıların kullanılması gösterilebilir.

Çalışmada, yapılan kümeleme analizi sonucunda birinci kümede yer alan 16 ülkenin 9'unun (\% 56,25), ikinci kümede yer alan 20 ülkenin 13'ünün (\% 65), ülkelerin tamamının olduğu analizde ise 36 ülkenin 21 'inin (\% 58,33) sağlı sistemi verimli bulunmuştur. Lorcu (2008)'nun AB'ye üye 27 ülke ve AB'ye aday Türkiye'nin dahil olduğu 28 ülkeyi karar verme birimi olarak kullandığ 1 çalışmasında girdi odaklı değişken getiri altında uygulanan VZA' da, girdiler 1.000 kişiye düşen yatak sayısı, GSYİH'dan sağlığa ayrılan pay, kişi başına düşen sağlık harcamaları ve 100.000 kişiye düşen pratisyen hekim sayısı; çıktılar ise beş yaş altı bebek ölüm hızı ve erkek yaşam beklentisi olarak belirlenmiştir. Lorcu (2008)'nun çalışmasında, bu çalışmadan farklı olarak Romanya etkin iken bu çalışmayla benzer olarak GKRK, Estonya, Finlandiya, İrlanda, İtalya, Polonya, Portekiz, Slovenya, İspanya, İsveç, Türkiye, Birleşik Krallık (İngiltere) ve Romanya'nın teknik etkin olduğu görülmektedir. Yine aynı çalışmada, bu çalışmada verimli bulunan Danimarka, Yunanistan, Lüksemburg, Letonya, Fransa ve Çek Cumhuriyeti verimsiz bulunurken bu çalışmayla benzer olarak Hollanda, Bulgaristan, Litvanya, Slovakya, Macaristan, Malta, Belçika, Almanya ve Avusturya verimsiz bulunmuştur.

Lorcu (2008)'nun, Türkiye'nin içinde bulunduğu kümedeki 11 ülkeyi karar verme birimi olarak kullandığı aynı çalışmada, girdi değişkeni olarak sadece GSYİH'dan sağlığa ayrılan pay; çıktı değişkeni olarak ise beş yaş altı çocuk ölüm hızı ve erişkinlerdeki sigara içme oranı kullanılmıştır. Lorcu (2008)'nun çalışmasında girdi odaklı değişken getiri altında uygulanan VZA'da, bu çalışmadan farklı olarak Bulgaristan ve Romanya etkin iken bu çalışmayla benzer olarak Estonya'nın teknik etkin olduğu görülmektedir. Yine aynı çalışmada, bu çalışmada 
verimli bulunan Letonya, Polonya, Çek Cumhuriyeti ve Türkiye verimsiz bulunurken bu çalışmayla benzer olarak Litvanya, Slovakya ve Macaristan verimsiz bulunmuştur.

Yıldırım ve Yıldırım (2011)'in 2000 yılı verilerini esas alarak AB'ye üye ve aday ülkelerin (27 ülke) sağlık sistemlerinin etkinliklerini; girdi değişkenlerinden toplam sağlık harcamalarının gayri safi yurt içi hasılaya (GSY IHH) oran1, 100.000 kişiye düşen hekim ve yatak sayıları, okullaşma beklentisi, 1 y1l içerisindeki kişi başı alkol tüketimi (litre); çıktı değişkenlerinden ise DBYS ve BÖO göstergelerini kullanarak, girdi yönelimli VZA tekniği ile karşılaştırdıkları başka bir çalışmada, bu çalışmada verimsiz bulunan Romanya, Malta ve Bulgaristan verimli bulunurken bu çalışmayla benzer olarak Türkiye, İtalya, İspanya, İsveç, Lüksemburg, Polonya, Birleşik Krallık, İrlanda ve Finlandiya verimli bulunmuştur. Yine aynı çalışmada, bu çalışmada verimli bulunan Letonya, Danimarka, Portekiz, Yunanistan, Slovenya, Fransa ve Çek Cumhuriyeti verimsiz bulunurken bu çalışmayla benzer olarak Estonya (kümeleme olduğunda verimli iken, kümeleme olmadığında verimsizdi), Avusturya, Hollanda, Belçika, Litvanya, Almanya, Slovakya ve Macaristan da verimsiz bulunmuştur.

Asandului, Roman ve Fatulescu (2014)'nun Türkiye'nin dahil olmadığ 30 Avrupa ülkesinin 2010 yılına ait verileri kullanarak yaptığı benzer bir çalışmada, girdi değişkenleri hekim sayısı, yatak sayısı ve kamu sağlık harcamasının GSYİH'ya oranı; çıktı değişkenleri ise DBYS ve BÖO olarak belirlenmiştir. Asandului, Roman ve Fatulescu (2014) çalışmasında girdi odaklı değişken getiri altında uygulanan VZA'da, bu çalışmadan farklı olarak Malta ve Romanya etkin iken bu çalışmayla benzer olarak GKRK, İtalya, İspanya, İsveç ve Birleşik Krallık'ın teknik etkin olduğu görülmektedir. Yine aynı çalışmada, bu çalışmada verimli bulunan Çek Cumhuriyeti, Danimarka, Finlandiya, Fransa, Yunanistan, İrlanda, Letonya, Lüksemburg, Polonya, Portekiz, Slovenya ve İzlanda verimsiz bulunurken bu çalışmayla benzer olarak Avusturya, Belçika, Bulgaristan, Estonya, Almanya, Macaristan, Litvanya, Hollanda, Slovakya, Hırvatistan ve Norveç verimsiz bulunmuştur.

Çalışmada, birinci kümede yer alan ülkelerin etkinlik skorları ortalaması $0,86 \pm 0,16$; ikinci kümede yer alan ülkelerin etkinlik skorları ortalamas1 $0,94 \pm 0,09$; ülkelerin tamamının (36 Avrupa ülkesinin) olduğu analizde ise etkinlik skorları ortalaması 0,89 $\pm 0,14$ bulunmuştur. Lorcu (2008)'nun çalışmasında, Türkiye'nin içinde olduğu kümedeki 11 ülkenin etkinlik skoru ortalaması $0,87 \pm 0,22$ bulunurken, ülkelerin tamamının (28 Avrupa ülkesinin) etkinlik skorları ortalaması $0,90 \pm 0,11$ bulunmuş olup bu çalışmayla benzerlik göstermektedir. Yıldırım ve Yıldırım (2011)'ın çalışmasında AB'ye üye ve aday 27 ülkenin etkinlik skorları ortalaması 0,96 $\pm 0,05$ bulunmuştur. Yıldırım ve Yıldırım (2011)'ın çalışmasıyla karşılaştırıldığında, bu çalışmada ikinci kümede yer alan ülkelerin etkinlik skorları ortalaması ile benzerlik gösterdiği görülmektedir. Asandului, Roman ve Fatulescu (2014)'nun çalışmasındaki 30 Avrupa ülkesinin etkinlik skorları ortalaması 
$(0,77 \pm 0,14)$ bu çalışmada birinci kümede yer alan ülkelerin etkinlik skorları ortalamasına $(0,86 \pm 0,16)$ daha yakın bulunmuştur.

Çalışmada, Türkiye birinci kümede yer almıştır ve VZA sonuçlarına göre kendi kümesinde hem verimli çıkmıştır hem de kendi kümesindeki verimsiz ülkelere en çok referans gösterilen (7) ülke durumundadır. Türkiye'nin girdileri ile içinde bulunduğu kümenin girdilerinin ortalaması karşılaştırıldığında, Türkiye'nin girdilerinin tamamının ortalaması küme 1'in ortalamasından daha düşük olmasına rağmen, DBYS daha uzun, OYS ise daha kısadır. Bunun yanı sıra BÖO ve AÖO daha yüksektir. Burada, girdi-çıktı değişkeleri baz alındığında, Türkiye'nin çok daha az girdiyle kendi kümesindeki ülkelere göre bazı çıktılarda (BÖO, AÖO) kötü durumda olsa da, bazı çıktılarda (DBYS, OYS) çok daha iyi durumda olduğundan, kendi kümesindeki diğer ülkelerin sağlık sistemlerine göre daha verimli bulunduğu düşünülmektedir.

Bunun bir sonucu olarak Türkiye (7) daha çok referans gösterilmiştir. Bu kümede referans gösterilme sıklığına göre Türkiye'yi; Arnavutluk (5), Karadağ (5) ve Estonya (4) takip etmiştir. Birinci kümede verimli çıan bütün ülkeler en az bir kere verimsiz çıkan ülkelere referans olarak gösterilmiştir. İkinci kümede yer alan ve verimli çıkan ülkeler arasında; Slovenya (3), Birleşik Krallık (3), İrlanda (3), GKRK (3) ve İspanya (3), söz konusu kümedeki verimsiz sağlık sistemine sahip ülkelere en çok referans gösterilen ülkelerdir. Ayrıca ikinci kümede yer alan Almanya ve Avusturya'nın sağlık sistemlerinin verimsiz ve etkinlik skorlarının da birbirine yakın olduğu görülmektedir. $\mathrm{Bu}$ durumun nedenleri arasında, bu iki ülkenin girdi değişkenlerinden KBSH ve çıktı değişkenlerinden DBYS ve BÖO göstergelerinin birbirine çok yakın olması ve hem sosyoekonomik hem de sağlık sistemleri açısından bu iki ülkenin birbirine benzer olması gösterilebilir. İkinci kümede verimli çıkmasına rağmen hiçbir ülkeye referans olarak gösterilmeyen tek ülke Fransa'dır. Tüm ülkelerin sağlık sistemlerinin verimliliğinin karşılaştıııldığında ise sağlı sistemi verimsiz olan ülkelere en çok referans gösterilen ülkeler; Arnavutluk (10), Türkiye (7) ve İspanya (7)'dır. Dikkat edilirse, Arnavutluk birinci kümede en çok referans gösterilen ikinci ülke iken tüm ülkelerin yer aldığı analizde en çok referans gösterilen ülkedir. Ayrıca, kümeleme olduğunda verimli çıkan Estonya, tüm ülkeler karşılaştırıldığında verimsiz çıkmıştır. Bunun sebebi olarak tüm ülkeler analize dahil edildiğinde karar verme birimleri (bu çalışma için ülkeler) sayısının artması ve bunun neticesinde kümelerdeki homojen yapının heterojen yapıya doğru kayması gösterilebilir. Bununla birlikte, bu durum VZA'nın doğasından da kaynaklanmış olabilir. Tüm ülkelerin yer aldığı analizde verimli çıkmasına rağmen hiçbir ülkeye referans olarak gösterilmeyen ülkeler Birleşik Krallık, Portekiz, Danimarka ve Çek Cumhuriyeti'dir. Lorcu (2008)'nun çalışmasında verimsiz ülkelere en fazla referans gösterilen ülkeler GKRK (11) ve Türkiye (8)'dir. Aynı çalışmada İtalya, Portekiz ve İspanya verimli olmasına rağmen hiçbir verimsiz ülkeye referans gösterilmemiştir. Lorcu (2008)'nun çalışması ile bu çalışma birlikte değerlendirildiğinde, her iki çalışmada da Türkiye en fazla referans gösterilen ikinci ülke durumundadır. Yıldırım ve Yıldırım 
(2011)'ın çalışmasında verimsiz ülkelere en fazla referans gösterilen ülkeler Finlandiya (15) ve İsveç (8)'tir. Aynı çalışmada Malta, verimli olmasına rağmen hiçbir verimsiz ülkeye referans gösterilmemiştir.

$\mathrm{Bu}$ çalışmanın ve diğer çalışmaların etkinlik durumları ve skorları, referans gösterilme durumları ile ilgili bulgular karşılaştırıldığında benzerlikler olduğu gibi farklılıkların da olduğu görülmektedir. Farklılıkların sebepleri arasında; 1) VZA'da kullanılan göstergelerin farklılık göstermesi, 2) bazı göstergeler aynı olsa bile farklı yıllara ait olması, 3) analize dahil edilen ülkelerin (veya karar birimlerinin) çoğu aynı olmasına rağmen sayı olarak farklılık göstermesi sayılabilir.

\section{SONUÇ}

Çalışmanın sonuçlarına göre, verimli bulunan ülkeler arasında olduğu gibi verimsiz bulunan ülkeler arasında da sağlık sonuçları hem iyi hem de kötü olan ülkeler mevcuttur. Yani, VZA sonucunda bir ülkenin verimli bulunması sağlık sonuçlarının iyi olmasını; verimsiz bulunması da sağlık sonuçlarının kötü olmasını garanti etmez. Bu durum, daha kötü sağlık sonuçlarına sahip bazı ülkelerin kaynaklarını görece daha verimli kullandığını göstermektedir. Ancak bu ülkelerin sağlık sonuçlarını da geliştirmeleri gerektiği de ortadadır. Sağlık sistemlerinin temel amacı toplumların sağlık statüsünü yükseltmektir. Sağlık sistemleri dışında toplumların sağlık statüsünü etkileyen faktörler arasında insanların içinde yaşadığ 1 toplum, fiziksel çevre, bireylerin yaşam tarzları ve sağlık davranışları gibi faktörler de yer almaktadır (OECD, 2015). Çalışmada kullanılan göstergeler değerlendirildiğinde, sağlık harcamasının fazla olmasının ülkelerin sağlık göstergelerinin iyileştirilmesi konusunda tek başına yeterli olmayacağı açıktır. Örneğin, bu çalışma kapsamında Hollanda’nın KBSH, ikinci kümenin ortalamasından yaklaşık \%25'i kadar daha fazla olmasına rağmen BÖO $(3,6)$ ve AÖO $(7,0)$, ikinci kümenin BÖO $(3,1)$ ve AÖO $(6,6)$ ortalamasından daha kötü durumdadır. Burada, sağlık harcamaları dışında ülkelerin kültürleri, insanların yaşam tarzları, sağlık sistemleri ve siyasilerin sağlık politikaları gibi sağlığın diğer belirleyicilerinin de sağlık sonuçları üzerinde önemli etkiye sahip olabileceği gerçeği ortaya çıkmaktadır. Sonuç olarak ülkeler; başta kötü performans sergiledikleri göstergeleri düzeltmek için çaba harcayabilir, daha iyi performans sergileyen ülkeler örnek alınarak bu ülkelerin uygulamalarını kendi sağlık sistemlerine uyarlama yoluna gidebilir veya kendi iç dinamiklerini tekrardan gözden geçirerek ve gerekli iyileştirmeleri yaparak daha iyi sağlık sonuçlarına sahip olabilir, nihayetinde de daha iyi performans gösterebilirler.

\section{KAYNAKÇA}

AB Bakanlığı, (2017). Erişim Tarihi 13 Aralık 2017, http://www.ab.gov.tr/109.html

Akkuş, Z., Sanisoğlu, S. Y., Akyol, M. ve Çelik, M. Y. (2006). Değişken Yapılarına Göre İstatistiksel Yaklaşım. Dicle Üniversitesi Tıp Fakültesi Dergisi, (33)2, 101-104.

Alkan, H. (2012). Kümeleme Analizi İle Elektrik Tüketiminin Sinıflandırılması. (Yüksek Lisans Tezi). Fırat Üniversitesi, Elazı $\breve{g}$.

Almeida, C., Braveman, P., Gold, M. R., Szwarcwald, C. L., Ribeiro, J. M., Miglionico, A. et al. (2001). Methodological Concerns and Recommendations on Policy Consequences of the World Health Report 2000. The Lancet, 357(9269), 1692-1697. 
Alpar, R. (2013). Uygulamalı Çok Değişkenli İstatistiksel Yöntemler, 4. Baskı, Ankara, Detay Yayıncilik.

Asandului, L., Roman, M. ve Fatulescu, P. (2014). The Efficiency of Healthcare Systems in Europe: A Data Envelopment Analysis Approach. Procedia Economics and Finance, 10, 261-268.

Aslan, Ş. (2007). Performans Ölçümünde Kiyaslama Yöntemi Olarak Veri Zarflama Analizinin Kullanımı: Türkiye Şeker Fabrikaları Örneği. Atatürk Üniversitesi İktisadi ve İdari Bilimler Dergisi, 21(1), 383-396

Ayanoğlu, Y., Atan, M. ve Beylik, U. (2010). Hastanelerde Veri Zarflama Analizi (VZA) Yöntemiyle Finansal Performans Ölçümü ve Değerlendirilmesi. Sağlıkta Performans ve Kalite, 2, 4062.

Bal, V. ve Bilge, H. (2013). Eğitim ve Araştırma Hastanelerinde Veri Zarflama Analizi İle Etkinlik Ölçümü. Manas Sosyal Araştırmalar Dergisi, 2(2), 1-14.

Banker, R. D., Charnes, A. ve Cooper, W. W. (1984). Some Models for Estimating Technical and Scale Inefficiencies in Data Envelopment Analysis. Management Science, 30(9), 10781092.

Behdioğlu, S. ve Özcan, A. G. G. (2009). Veri Zarflama Analizi ve Bankacilık Sektöründe Bir Uygulama. Süleyman Demirel Üniversitesi İktisadi ve İdari Bilimler Fakültesi Dergisi, 14(3), 301-326.

Blendon R. J., Kim M., Benson J. M. (2001) The Public Versus The World Health Organization on Health System Performance, Health Affairs. 20(3), 10-20.

Boles, J.S., Donthu, N. ve Lohtia, R. (1995). Salesperson Evaluation Using Relative Performance Efficiency: The Application of Data Envelopment Analysis. Journal of Personal Selling and Sales Management, 15(3), 31-49.

Charnes, A., Cooper, W. ve Rhodes, E. (1978). Measuring the Efficiency of Decision Making. European Journal of Operational Research, 2(6), 429-44.

Charnes, A., Cooper, W. ve Rhodes, E. (1981). Evaluating Program and Managerial Efficiency: An Application of Data Envelopment Analysis to Program Follow Through. Management Science, 27(6), 668-697.

Charnes, A., Cooper, W., Lewin, A. Y. ve Seiford, L. (1994). Data Envelopment Analysis: Theory, Methodology And Applications, London, Kluwer.

Cooper, W. Seiford, L. M. ve Tone, K. (2007). Data Envelopment Analysis, Second Edition, New York, Springer.

Demir, P., Derbentli, Ö. ve Sakarya, E. (2012). Kars İlinde Bulunan Mandıraların Etkinliğinin Veri Zarflama Analizi İle Ölçülmesi. Kafkas Üniversitesi Veteriner Fakültesi Dergisi, 18 (2), 69 176.

Farrell, M. J. (1957). The Measurement of Productive Efficiency. Journal of the Royal Statistical Society Series A (General), 120(3), 253-290.

Golany, B. ve Roll, Y. (1989). An Application Procedure for DEA. Omega, 17 (3), 237-250.

Gülsevin, G. ve Türkan, A. H. (2012). Afyonkarahisar Hastanelerinin Etkinliklerinin Veri Zarflama Analizi ile Değerlendirilmesi. Afyon Kocatepe Üniversitesi Fen ve Mühendislik Bilimleri Dergisi 12(2), 1-8.

Güran, M. C. ve Tosun, M. U. (2005). Türkiye Ekonomisinin Makroekonomik Performansı: 1951 2003 Dönemi İçin Parametrik Olmayan Bir Ölçüm. Ankara Üniversitesi SBF Dergisi, 60(4), 89-115.

İlkay, M. S. ve Doğan, N. Ö. (2009). Veri Zarflama Analizi İle Kapadokya Bölgesindeki Belediyelerin Etkinlik Ölçümü: 2004 ve 2008 Yıllarına İlişkin Bir Karş1laştırma. Erciyes Üniversitesi İktisadi ve İdari Bilimler Fakültesi Dergisi, 32, 191-218.

Kocaman, A.M., Mutlu, M. E., Bayraktar, D. ve Araz, Ö. M. (2012). OECD Ülkelerinin Sağlık Sistemlerinin Etkinlik Analizi. Endüstri Mühendisliği Dergisi, 23(4), 14-31.

Köktaş, M. A. (2014). Sağlık Ekonomisi, Ankara, 657 Yayınevi.

LaPlante, A. E. ve Paradi, J. C. (2015). Evaluation of Bank Branch Growth Potential Using Data Envelopment Analysis. Omega, 52, 33-41. 
Lorcu, F. (2008). Veri Zarflama Analizi (DEA) ile Türkiye ve Avrupa Birliği Ülkelerinin Sağlık Alanındaki Etkinliklerinin Değerlendirilmesi. (Doktora Tezi), İstanbul Üniversitesi, İstanbul.

Narc1, H. Ö. (2012). Sağlık Kurumlarında Verimlilik Ölçümü ve Yöntemleri, İsmet Şahin ve Narc1 H.Ö. (Eds.) Sağlık Kurumlarında Operasyon Yönetimi, Eskişehir: T.C. Anadolu Üniversitesi Yayını.

Navarro V. (2000) Assessment of The World Health Report 2000, The Lancet. 356(4), 1598-1601.

OECD, (2015). Health at a Glance 2015: OECD Indicators, Paris, OECD Publishing.

OECD, (2017). Erişim Tarihi 30 Kasım 2017, http://www.oecd.org/health/

OECD, (2017). Erişim Tarihi 30 Kasım 2017, http://www.oecd.org/health/health-at-a-glance-europe23056088.htm

Okursoy, A. ve Özdemir, M. (2015). Veri Zarflama Analizinde Homojen Olmayan Karar Verme Birimi Problemi için Kümeleme Analizi Yaklaşımı. Ege Akademik Bakış, 15(1), 81-90.

Özdamar, K. (2013). Paket Programlar ile İstatistiksel Veri Analizi, Cilt 2, 9. Bask1, Ankara, Nisan Kitapevi.

Öztürk, F. (2012). Kümeleme Analizi ve Uygulaması. (Yüksek Lisans Tezi). İstanbul Ticaret Üniversitesi, İstanbul.

Preker, A. S. ve Carrin, G. (2004). Health Financing for Poor People: Resource Mobilization And Risk Sharing, Washington D.C., The World Bank.

Rosko, M. D. (1990). Measuring Technical Efficiency in Health Care Organizations. Journal of Medical Systems, 14(5), 307-322.

Sarı, Z. (2015). Veri Zarflama Analizi ve Bir Uygulama. (Yüksek Lisans Tezi). Hacettepe Üniversitesi Fen Bilimleri Enstitüsü, Ankara.

Şahin, İ. (1998). Sağlık Bakanlığı Hastanelerinin İllere Göre Karşılaştırmalı Verimlilik Analizi: Veri Zarflama Analizine Dayalı Bir Uygulama. (Doktora Tezi). Hacettepe Üniversitesi Sağlık Bilimleri Enstitüsü, Ankara.

Şahin, İ. (1999). Sağlık Kurumlarında Göreceli Verimlilik Ölçümü: Sağlık Bakanlığı Hastanelerinin İllere Göre Karşılaştırmalı Verimlilik Analizi. Amme İdaresi Dergisi, 32(2), 124-145.

Tekin, B. (2015). Temel Sağlık Göstergeleri Açısından Türkiye'deki İllerin Gruplandırılması: Bir Kümeleme Analizi Uygulaması. Çankırı Karatekin Üniversitesi İïB Dergisi, 5(2), 389416.

Uğurluoğlu, Ö. ve Çelik, Y. (2005). Sağlık Sistemleri Performans Ölçümü, Önemi ve Dünya Sağlık Örgütü Yaklaşımı. Hacettepe Sağlık İdaresi Dergisi, 8(1), 3-29.

WHO, (2000). The World Health Report 2000: Health Systems: Improving Performance, Switzerland, WHO.

WHO, (2017). Erişim Tarihi 30 Kasım 2017, http://apps. who.int/gho/data/node.home

WHO, (2017). Erişim Tarihi 30 Kasım 2017, http://www.euro.who.int/_data/assets/pdf_file/ 0019/290440/Core-Health-Indicators-European-2015-human-resources-health.pdf?ua=1

WHO, (2017). Erişim Tarihi 30 Kasım 2017, https://gateway.euro.who.int/en/indicators/hfa_5406100-average-length-of-stay-all-hospitals/

World Bank, (2017). Erişim Tarihi 30 Kasım 2017, http://databank.worldbank.org/data/reports.aspx? ource=world-development-indicators

Yıldırım, H. H. (2012). Sağlık Harcamaları ve Sağlı Finansmanı. Hasan Hüseyin Yıldırım (Ed.) Sağlık Sigortacılığı, Eskişehir: T.C. Anadolu Üniversitesi Yayını.

Yıldırım, H. H. ve Yıldırım, T. (2011). Avrupa Birliğine Üyelik Sürecinde Türkiye Sağlık Sektörü, 2. Bask1, Ankara, İmaj Yayınevi.

\section{SUMMARY}

The factors that hamper the success of health systems are the systemic failures rather than technical limitations, that is, the main reason for the failure of health systems is not the lack of knowledge, but not the full implementation of what is known. This necessitates comparing the current performance of health systems 
and discussing how they can realize their potentials. In this context, the efficiency performance of the health systems of countries in the European Union (EU) cycle is compared with data envelopment analysis (DEA). Prior to comparison, clustering analysis was performed to ensure the homogeneity of the clusters within themselves while to ensure the heterogenity between themselves. It can be said that the countries in the EU cycle can be roughly gathered in 2 clusters for the purpose of this study. The first cluster had 16 countries, including Turkey and the second cluster had 20 countries which are relatively more developed than those in the first cluster. In terms of the variables used in this study, 56.25\% of the countries in the first cluster and $65 \%$ of the countries in the second cluster were found to be efficient. Within the scope of the study, a DEA which contained all the countries was also conducted without clustering analysis and accordingto the results, $58 \%$ of all the countries were found to be efficient. 